\title{
The effects of a ration change from a total mixed ration to pasture on health and production of dairy cows
}

\author{
M. Schären, ${ }^{*}$ S. Jostmeier, ${ }^{*}$ S. Ruesink, ${ }^{*}$ L. Hüther, ${ }^{*}$ J. Frahm, ${ }^{*}$ M. Bulang, † U. Meyer, ${ }^{* 1}$ J. Rehage,‡ \\ J. Isselstein,§ G. Breves,\# and S. Dänicke* \\ *Institute of Animal Nutrition, Friedrich-Loeffler-Institute (FLI), Federal Research Institute for Animal Health, Bundesallee 50, 38116 Brunswick, \\ Germany \\ †Institute of Agricultural and Nutritional Sciences, Martin-Luther-University Halle-Wittenberg, Karl-Freiherr-von-Fritsch-Str. 4, 06120 Halle (Saale), \\ Germany \\ ¥Clinic for Cattle, University of Veterinary Medicine Hannover, Bischofsholer Damm 15, 30173 Hannover, Germany \\ §Department of Crop Sciences, Grassland Science, Georg-August University Göttingen, Von-Siebold-Str. 8, 37077 Göttingen, Germany \\ \#Department of Physiology, University of Veterinary Medicine Hannover, Bischofsholer Damm 15, 30173 Hannover, Germany
}

\begin{abstract}
In pasture-based dairy production systems, dairy cows often receive a silage- and concentrate-based ration [total mixed ration (TMR)] during wintertime and are gradually introduced to fresh herbage in spring. The present study aimed to investigate how the transition to this new nutritional situation influenced different production and health indicators. A 10-wk trial was performed in spring 2014, including 60 dairy cows of the German Holstein breed $(166 \pm 23 \mathrm{~d}$ in milk, $23.5 \pm$ $3.7 \mathrm{~kg}$ of milk/d; means $\pm \mathrm{SD}$ ). The cows were divided into a pasture and a confinement group (PG and CG, respectively). The $\mathrm{CG}$ stayed on a TMR-based diet (35\% corn silage, $35 \%$ grass silage, $30 \%$ concentrate; DM basis), whereas the PG was gradually transitioned from a TMR- to a pasture-based ration (wk $1=$ TMRonly, wk $2=3 \mathrm{~h} / \mathrm{d}$ on pasture, wk 3 and $4=12 \mathrm{~h} / \mathrm{d}$ on pasture, wk 5-10= pasture-only). A continuous grazing system was implemented on a ryegrass dominated pasture and temperature humidity indices were assessed based on continuous recording of temperature and humidity indoors as well as outdoors. Dry matter intake (DMI) from TMR, milk production, body weight (BW), and body condition score decreased as soon as the PG had partial access to pasture. Milk production and BW decreased even further in the first week on a full grazing ration, but thereafter BW increased again and milk production stabilized. The DMI estimation using the n-alkane method in wk 7 and 9 revealed an increase in DMI from pasture between the 2 time points and indicates an adaptation of grazing behavior and metabolism over several weeks. Increased serum
\end{abstract}

Received May 17, 2015.

Accepted October 3, 2015.

${ }^{1}$ Corresponding author: Ulrich.Meyer@fli.bund.de $\beta$-hydroxybutyrate and fatty acids concentrations at several time points, as well as a continuous body condition score decrease during the whole course of the trial, indicate an energy deficit in the PG. A significant correlation between serum glucose concentrations and the temperature humidity indices was observed. An increase in serum and milk urea concentrations as well as an increase in the urine total $\mathrm{N}$ to creatinine ratio occurred in the PG. To assess possible negative effects of the ration change on metabolic and liver health, different clinical chemistry variables and complete blood counts were assessed. No biologically relevant changes were observed for serum albumin, total protein, cholesterol, aspartate transaminase, $\gamma$-glutamyltransferase, and glutamate dehydrogenase concentrations, as well as for white and red blood cell counts.

Key words: pasture, confinement, ration change, health

\section{INTRODUCTION}

In temperate climate zones, dairy cows are often fed a TMR during winter and are gradually transitioned to a pasture-based ration in spring. Especially for farms with a seasonal calving pattern, milk production from pasture can be economically beneficial due to lower production costs. Also, larger demand for pasture-based milk products, higher feed costs, and volatile milk prices have made grazing dairy systems more attractive in recent years (Dillon et al., 2005). Pasture-based rations generally exhibit a higher $\mathrm{CP}$ and lower ME content. Due to this imbalance in available nutrients, a lower DMI, and a higher energy demand, grazing dairy cows generally have a lower milk production when no dietary attempts are made for counterbalancing (Osuji, 1974; Kolver, 2003; Roca-Fernandez et al., 2013). Milk production can be supported by a pasture-based ration up 
to 25 to $30 \mathrm{~kg}$ of milk/d, whereas a TMR can support milk production of more than $40 \mathrm{~kg}$ of milk/d (Kolver and Muller, 1998; Bargo et al., 2002).

Different studies have shown that in a grazing- compared with a TMR-based system cows of high-yielding breeds with similar production potential, in particular, are subjected to a more pronounced negative energy balance after calving; as a consequence, these cows undergo a more extensive loss of BW (Washburn et al., 2002; Fontaneli et al., 2005; O'Neill et al., 2011) and exhibit higher serum BHB and fatty acids concentrations postpartum (Kolver and Muller, 1998; Bargo et al., 2002). However, until now no clear evidence has been found that this inferior metabolic and nutritional status is related to an increased incidence of health or reproductive problems (Olmos et al., 2009b; Alawneh et al., 2012; Ribeiro et al., 2013). Further, different studies suggest that pasture-based compared with confinement systems are more beneficial regarding different general health related traits, such as mortality (Burow et al., 2011), udder health (Goldberg et al., 1992; Washburn et al., 2002), and lameness incidence (Haskell et al., 2006; Olmos et al., 2009a), but elaborate studies are lacking.

Due to the limitations of ME supply and a high CP intake, the nitrogen efficiency of grazing dairy cows is generally lower (Kolver, 2003). Excess N is converted into urea by the liver and excreted mainly via milk and urine. Urea synthesis incurs a metabolic energy cost which imposes an additional metabolic effort on a system already limited by energy supply (Kolver, 2003). Several studies indicate that $\mathrm{NH}_{3}$ in high metabolic concentrations has a toxic effect and incriminates different organs in their function (Rajala-Schultz et al., 2001; Pacheco and Waghorn, 2008; Keim and Anrique, 2011). It has been shown in confinement systems that high metabolic urea concentrations are associated with reduced fertility (summarized in Pfeffer and Hristov, 2005). Moller et al. (1993) confirmed this correlation in a study including several pasture-based dairy farms. Contrary to this conclusion, Smith et al. (2001) could not find any relationship between milk urea $\mathrm{N}$ content and reproductive performance of pasture-fed New Zealand dairy herds.

In a pasture-based system, in contrast to a confinement TMR-based system, the chemical composition of the ration as well as the cows themselves are much more subjected to the influence of weather. Grazing dairy cows have to deal with changes in protein and energy availability not only seasonally, but sometimes also daily and weekly (Parker and Edwards, 1996; Smit et al., 2004; Abrahamse et al., 2009), and are often more exposed to certain weather conditions, such as rain, wind, and heat (Legrand et al., 2009).
Thus, in pasture-based as well as confinement systems, different management aspects form challenges regarding cow performance as well as welfare. However, no studies that we know of have been published focusing on the effect of the transition from a TMR to a pasture-based ration on dairy cow production and health. It is generally accepted that animal behavior and metabolism, as well as the rumen microbiota, need to adapt to a new nutritional situation; therefore, farmers are advised to introduce cows to pasture gradually over several weeks. But data illustrating the effect of this nutritional change and duration of adaption are lacking.

Thus, we hypothesized that the change from a confinement to a pasture-based system involves complex nutritional and metabolic adaptations with consequences on health and performance. Therefore, the objective of our study was to investigate the influence of a ration change from TMR to pasture on DMI, body condition, milk production, $\mathrm{N}$ metabolism, and health. A 10-wk trial with 2 groups (TMR only vs. gradual transition from TMR to pasture) with repeated measurements was conducted to assess the effect and duration of the adaption period.

\section{MATERIALS AND METHODS}

Experimental work was conducted from April until June 2014 at the experimental station of the Friedrich Loeffler Institute (FLI) in Brunswick, Germany. The experiment was carried out according to the German Animal Welfare Act approved by the Lower Saxony State Office for Consumer Protection and Food Safety (LAVES, Oldenburg, Germany).

\section{Experimental Design and Treatments}

Sixty primi- and pluriparous German Holstein cows $(166 \pm 23$ DIM; mean \pm SD) were randomly assigned to either a pasture group (PG; $\mathrm{n}=29)$ or a confinement group $(\mathbf{C G} ; \mathrm{n}=31$ ). Each group contained $5 \mathrm{ru}-$ men- and duodenum-fistulated animals. Cows had been exposed to intensive grazing before their first calving and during dry periods in previous seasons. Treatments were balanced for milk production $(23.5 \pm 3.7 \mathrm{~kg}$ of milk/cow per day), BW (613 $\pm 48 \mathrm{~kg}), \mathrm{BCS}(3.1 \pm 0.6$; 5-point scale; Edmonson et al., 1989), and mean number of lactations $(1.9 \pm 1.6)$. The experimental period lasted 10 wk from April 21 until June 27, 2014. In the months preceding the trial, a TMR (similar components as fed during the trial) and additional concentrate to match individual milk production (available at an automated feeding station) were fed. Two weeks before the trial, all cows were switched to the trial TMR and individual 
Table 1. Ingredients of concentrates ${ }^{1}$

\begin{tabular}{lccc}
\hline $\begin{array}{l}\text { Ingredient } \\
(\% \text { DM) }\end{array}$ & $\begin{array}{c}\text { Concentrate } \\
\text { TMR CG }\end{array}$ & $\begin{array}{c}\text { Concentrate } \\
\text { TMR PG }\end{array}$ & $\begin{array}{c}\text { Concentrate } \\
\text { PG }\end{array}$ \\
\hline Soybean meal & 15.8 & 15.8 & - \\
Rapeseed meal & 11.0 & 11.0 & - \\
Wheat & 21.4 & 21.4 & 29.6 \\
Corn & 21.5 & 21.5 & 29.6 \\
Barley & 21.5 & 21.5 & 29.6 \\
Dried sugar beet pulp & 5.0 & 5.0 & - \\
Feed lime & 1.5 & 1.5 & - \\
Soybean oil & 1.0 & 1.0 & 1.0 \\
Mg-oxide $_{\text {Mineral feed }}^{2}$ & - & 0.3 & 1.2 \\
\hline CG & 1.2 & 1.2 & 9.0 \\
\hline
\end{tabular}

${ }^{1} \mathrm{CG}=$ confinement group; $\mathrm{PG}=$ pasture group.

${ }^{2}$ Per kilogram of mineral feed: $140 \mathrm{~g}$ of $\mathrm{Ca} ; 120 \mathrm{~g}$ of Na; $70 \mathrm{~g}$ of $\mathrm{P} ; 40$ $\mathrm{g}$ of $\mathrm{Mg} ; 6 \mathrm{~g}$ of $\mathrm{Zn} ; 5.4 \mathrm{~g}$ of Mn; $1 \mathrm{~g}$ of $\mathrm{Cu} ; 100 \mathrm{mg}$ of I; $40 \mathrm{mg}$ of Se; $25 \mathrm{mg}$ of Co; $1,000,000 \mathrm{IU}$ of vitamin A; 100,000 IU of vitamin $\mathrm{D}_{3}$; and $1,500 \mathrm{mg}$ of vitamin $\mathrm{E}$.

concentrate feeding was ceased. The CG stayed on a TMR-based diet during the entire trial whereas the PG was slowly introduced to a pasture-based ration: wk 1 $=\mathrm{TMR}$, wk $2=\mathrm{TMR}$ and $3 \mathrm{~h}$ of pasture $/ \mathrm{d}$, wk 3 and $4=\mathrm{TMR}$ and $12 \mathrm{~h}$ of pasture $/ \mathrm{d}$, wk 5 to $10=$ pasture and $1.75 \mathrm{~kg}$ of DM concentrate/d. The TMR consisted of $35 \%$ corn silage, $35 \%$ grass silage, and $30 \%$ concentrate. To prevent the risk of hypomagnesaemia, $\mathrm{MgO}$ was added to the TMR and concentrate of the PG. The components and chemical composition of the different experimental diets are illustrated in Tables 1 and 2 . The cows were milked 2 times per day at 0530 and 1500 $\mathrm{h}$. The TMR was fed daily at approximately $1100 \mathrm{~h}$. In wk 5 to $10,0.88 \mathrm{~kg}$ of DM concentrate was offered to the $\mathrm{PG}$ in troughs after morning and evening milking. Pastures were located directly adjacent to the barn, including the milking parlor, with a walking distance averaging less than $100 \mathrm{~m}$.

\section{Pasture Management}

A continuous grazing system was implemented with 2 pastures, measuring 6 ha each (pasture 1 and 2). Depending on pasture height, weather, and management decisions, such as irrigation, one or the other pasture was used (stocking density $=2.5$ animals/ ha). The average pasture height was measured 3 times per week using an electronic rising plate meter (RPM F400, Farmworks Systems Ltd., Manawatu-Wanganui, New Zealand). Daily pasture allowances were estimated using exclosure cages (described herein). Plant species and their estimated pasture coverage were assessed in wk 1 . The pastures were situated on sandy loamy soil and sufficiently supplied with plant available P, K, and $\mathrm{Mg}$ (soil sampling 6 mo before the trial; pasture 1: $\mathrm{pH}$ $=5.5, \mathrm{P}=5.3 \mathrm{mg} / 100 \mathrm{~g}, \mathrm{~K}=11.6 \mathrm{mg} / 100 \mathrm{~g}, \mathrm{Mg}=10$ $\mathrm{mg} / 100 \mathrm{~g}$; pasture $2 \mathrm{pH}=6.3, \mathrm{P}=9.6 \mathrm{mg} / 100 \mathrm{~g}, \mathrm{~K}$ $=11.7 \mathrm{mg} / 100 \mathrm{~g}, \mathrm{Mg}=10 \mathrm{mg} / 100 \mathrm{~g})$. Both pastures were fertilized with approximately $40 \mathrm{~kg}$ of N/ha $1 \mathrm{mo}$ preceding the trial and every 4 to $6 \mathrm{wk}$ thereafter [total annual fertilization $=137$ (pasture 1$)$ and $107 \mathrm{~kg}$ of N/ ha (pasture 2) with either calcium ammonium nitrate, ammonium nitrate urea solution, or liquid manure].

\section{Weather and Barn Climate Measurements}

Daily mean temperature and humidity, as well as minima and maxima, were recorded by a weather station of the "Deutscher Wetterdienst" adjacent to the pastures (station no. $662 ; 52^{\circ} 17^{\prime} 29^{\prime \prime} \mathrm{N}, 10^{\circ} 26^{\prime} 47^{\prime \prime} \mathrm{E}$ ). Barn climate (temperature and humidity) was recorded every 10 min via data loggers (Tinytag Plus 2, TGP-4500, Gemini Data Loggers, Chichester, UK). The climate conditions were characterized by the calculation of the

Table 2. Chemical composition of experimental $\operatorname{diets}^{1}$

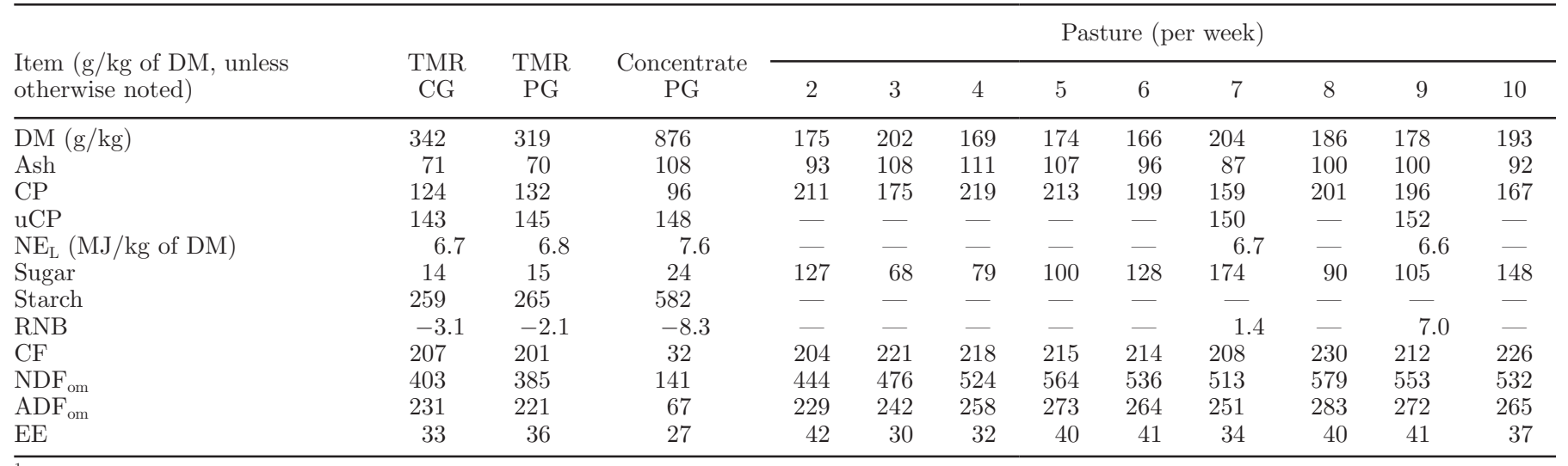

${ }^{1} \mathrm{CG}=$ confinement group $\mathrm{PG}=$ pasture group $\mathrm{uCP}=$ utilizable crude protein; $\mathrm{RNB}=$ ruminal nitrogen balance $; \mathrm{CF}=\mathrm{crude}$ fiber; $\mathrm{NDF}$ om $=$ neutral detergent fiber; $\mathrm{ADF}_{\mathrm{om}}=$ acid detergent fiber; $\mathrm{EE}=$ ether extract. $\mathrm{NDF}$ and $\mathrm{ADF}$ were expressed without residual ash and are therefore referred to as $\mathrm{NDF}_{\text {om }}$ and $\mathrm{ADF}_{\mathrm{om}}$. 
daily temperature humidity indices (THI) described in Hahn (1999).

\section{Pasture and Feed Measurements}

Representative TMR and silage samples were collected daily and pooled over 4-wk periods and concentrate samples were taken representatively during the manufacturing process. Pasture samples were collected 3 times per week in the morning along a defined pathway using an electric mower, selected and cut representatively according to observed grazing behavior (only where cows were currently grazing and only the upper half of the plant), and pooled per pasture and week. Feed samples were then dried at $60^{\circ} \mathrm{C}$ for $72 \mathrm{~h}$ and ground to pass through a $1.0-\mathrm{mm}$ screen. The chemical composition was analyzed according to the methods of the VDLUFA (2006; method numbers are given) for DM (3.1), ash (8.1), CP (Dumas method, 4.1.2), starch (7.2.1), sugar (Luff-Schoorl method, 7.1.2), ether extract (5.1.1), crude fiber (6.1.1), NDF (6.5.1), and ADF (6.5.2; NDF and ADF were expressed without residual ash). Utilizable CP, ruminal nitrogen balance (RNB), and $\mathrm{NE}_{\mathrm{L}}$ of silage and pasture samples were determined by near infrared spectroscopy (according to VDLUFA, 2006) and calculations according to GfE (2008). For calculations of utilizable $\mathrm{CP}, \mathrm{RNB}$, and $\mathrm{NE}_{\mathrm{L}}$, contents of concentrates tables values according to DLG (1997) and calculations according to GfE (2001) were used. A weekly average for the pasture chemical composition was calculated in consideration of the amount of days cows were on pasture 1 or 2 in the respective week.

\section{Animal Measurements}

DMI. In the confinement system, individual water and TMR intake was continuously recorded using electronic weighing troughs and radio frequency identification (in wk 1-4 in PG and throughout the whole trial in CG; Insentec, B.V., Markenesse, the Netherlands). The concentrate which was fed in the PG in wk 5 to 10 was individually fed after milkings, and if some concentrate remained it was weighed back (which was rarely the case and found negligible). In the PG, daily pasture allowances and group DMI were estimated 3 times in wk 5 to 10 using 12 exclosure cages (each $2.75 \mathrm{~m}^{2}$ ). Every 10 to $14 \mathrm{~d}$, the grass grown underneath each exclosure cage and a reference area next to it was harvested, weighed, and the DM content was determined. The average growth rate was determined by subtracting the amount of DM harvested from the reference area before the growth period from the amount of DM underneath the exclosure cage and extrapolating it to kilograms per hectare per day. The estimated average growth rate was then used to assess the average pasture allowance in kilograms per cow per day. The average DMI was estimated by subtraction of the amount of DM harvested from the reference area from the amount DM underneath the exclosure cage and extrapolation to kilograms of DM per cow per day. To estimate the individual pasture DMI, the n-alkane method was used (Dove and Mayes, 2006). The C32 alkane (800 g; Th-Geyer, Renningen, Germany; VWR, Darmstadt, Germany; Sigma-Aldrich, Seelze, Germany) was mixed into $1,800 \mathrm{~kg}$ of concentrate (3 batches of $600 \mathrm{~kg}$ ) as described by Taweel et al. (2006). Concentrate samples were collected representatively during the manufacturing process (4 samples per batch) and analyzed thereafter to assess marker distribution before the trial. The marker was evenly distributed within batches, but slightly different between batches (batch $1=342$ \pm 8.5 ; batch $2=363 \pm 4.7$; batch $3=372 \pm 9.2$ $\mathrm{mg} / \mathrm{kg}$ of DM; means $\pm \mathrm{SD}$ ). Therefore, batches were mixed thoroughly before feeding and the average of the measured concentrations (359 $\mathrm{mg}$ of $\mathrm{C} 32 / \mathrm{kg}$ of $\mathrm{DM}$ ) was used for DMI calculation. During wk 6 to 9 of the trial, $0.88 \mathrm{~kg}$ of DM of this concentrate was fed twice daily after milking. In wk 7 and 9, grass and individual feces samples were collected twice daily after milking and stored at $-20^{\circ} \mathrm{C}$. At the end of each week the feces samples were pooled per animal. The pooled feces samples and each grass sample were freeze-dried and ground to pass a 1-mm screen. Samples were analyzed for n-alkanes as described in Elwert et al. (2004). The DMI was calculated using the n-alkane pairs C31:C32 and C33:C32 as follows (Dove and Mayes, 1996):

$$
\begin{gathered}
\text { DMI }(\mathrm{kg} \text { of DM } / \mathrm{d})=\left(\mathrm{F}_{\mathrm{i}} / \mathrm{F}_{\mathrm{j}}\right) \\
\times \mathrm{D}_{\mathrm{j}} /\left[\mathrm{G}_{\mathrm{i}}-\left(\mathrm{F}_{\mathrm{i}} / \mathrm{F}_{\mathrm{j}}\right) \times \mathrm{G}_{\mathrm{j}}\right],
\end{gathered}
$$

where $\mathrm{F}=$ average concentration of $\mathrm{n}$-alkane in feces $(\mathrm{mg} / \mathrm{kg}$ of DM), $\mathrm{G}=$ average concentration of n-alkane in grass-sample $(\mathrm{mg} / \mathrm{kg}$ of $\mathrm{DM}), \mathrm{D}=$ daily dosage of n-alkane marker $(\mathrm{mg}), \mathrm{i}=$ marker alkane $(\mathrm{C} 32)$, and $\mathrm{j}$ = natural herbage alkane (C31 or C33).

Milk and $\boldsymbol{B} \boldsymbol{W}$. Individual milk yields were recorded daily and BW was automatically recorded when leaving the milking parlor. Morning and evening milk samples were collected at $2 \mathrm{~d} /$ wk (Monday evening and Tuesday morning; Thursday evening and Friday morning) and stored at $4^{\circ} \mathrm{C}$ until analysis. Milk samples were analyzed for fat, protein, lactose, urea, and SCC concentrations using an infrared milk analyzer (Milkoscan FT 6000 combined with a Fossomatic 5000; Foss Electric A/S, Hillerød, Denmark). Body condition score was recorded 
every $14 \mathrm{~d}$ using a 5-point scale according to Edmonson et al. (1989).

Blood. Blood samples were collected weekly from the Vena caudalis mediana in a $10-\mathrm{mL}$ evacuated serum separating blood tube and a $10-\mathrm{mL}$ blood tube containing EDTA to prevent coagulation. A complete blood count (electrical resistance detection) of each sample was performed within $2 \mathrm{~h}$ after sampling using an automated hematology analyzer (Celltac $\alpha$ MEK-6450, Nihon Kohden Corporation, Tokyo, Japan; including hemoglobin (surfactant or colometric method), hematocrit, white blood cell population, and red blood cell and platelet distribution width (based on histogram calculation). The serum was separated (centrifuged at 2,123 $\times g$ for $15 \mathrm{~min}$ at $15^{\circ} \mathrm{C}$ ) and stored at $-80^{\circ} \mathrm{C}$ before chemical analysis using an automatic clinical chemistry analyzer (Eurolyser CCA180, Eurolab, Salzburg, Austria; analysis methods are indicated in brackets following variables). Serum glucose (enzymatic colorimetric, glucose oxidase enzyme-peroxidase antiperoxidase), BHB, fatty acids (both enzymatic colorimetric), and urea concentrations were determined weekly. Serum albumin (bromocresol green), total protein (biuret), cholesterol (cholesterol oxidase-peroxidase antiperoxidase), aspartate transaminase (AST; with pyridoxal phosphate), $\gamma$-glutamyltransferase $(\boldsymbol{\gamma}$-GT), total bilirubin (2,4-dichlorophenyldiazonium), glutamate dehydrogenase (GLDH), and triglyceride (glycerol-3-phosphate) concentrations were measured in wk 1, 6, and 10. All metabolites were determined using commercial kits (Greiner Diagnostic, Bahlingen, Germany) according to the manufacturer's instructions.

Urine. Midstream urine samples were collected weekly during voluntary urination of cows either in the barn or on pasture. Urine $\mathrm{pH}$ was measured immediately after collection using a glass electrode (digital $\mathrm{pH}$ measurement devise, $\mathrm{pH}$ 525, WTW, Weilheim, Germany). Samples for total N analysis were directly stored at $-20^{\circ} \mathrm{C}$. Samples for creatinine, allantoin, and uric acid analysis were directly cooled to $4^{\circ} \mathrm{C}$. For further preparation samples were brought to room temperature, homogenized, diluted 1:50, and stored at $-20^{\circ} \mathrm{C}$ on the same day. Weekly urinary creatinine, allantoin, and uric acid concentrations were determined using reverse-phase chromatography (HPLC system, Shimadzu, Kyoto, Japan). After filtration (amcro filter, polyvinylidene fluoride, $0.45 \mu \mathrm{m}$; Kinesis Ltd., St. Neots, UK), $20 \mu \mathrm{L}$ of samples were injected into a HPLC system. Samples were run through a C18 column (Inertsil ODS, GL Sciences B.V., Einthoven, the Netherlands, $150 \times 3 \mathrm{~mm}, 5 \mu \mathrm{m}$ particle size, 150 $\AA$ pore size) using an binary gradient system. Mobile phase A consisted of $0.5 \%$ acetonitrile, $10 \mathrm{~m} M$ IPCC6 in ultrapure water at a $\mathrm{pH}$ of 2.3 , and mobile phase B of $100 \%$ acetonitrile. Quantification was performed by a multi-wavelength detector at wavelengths of 218 (allantoin), 225 (creatinine), and $284 \mathrm{~nm}$ (uric acid; described in detail in Winkler et al., 2014). Nitrogen concentrations were determined in wk 1, 4, 7, and 10 using the Kjeldahl method.

\section{Statistical Analysis}

If variables were recorded more than once a week, means were calculated per cow and week prior to being subjected to statistical evaluation. Repeated measurements were analyzed using PROC MIXED in SAS Enterprise Guide 6.1 (SAS Institute Inc., Cary, NC) using a restricted maximum likelihood model (REML). Week and diet group and their interaction were defined as fixed factors. To account for the individual variation of the cows a REPEATED statement was included. Best fitting covariance structures were tested using the Akaike information criterion for a finite sample size (AICC). Significant weekly effects were further evaluated by multiple $t$-test (procedure PDIFF) with Tukeyadjusted $P$-values. Multiple comparisons were presented within experimental groups to describe time effects within groups (indicated by different letters), whereas group differences were evaluated for corresponding time points only (indicated by symbols). Results are presented as least squares means and pooled standard error of means (PSEM). Correlation coefficients between different traits were estimated using Statistica 12.0 (StatSoft Inc., Tulsa, OK).

\section{RESULTS}

\section{Weather and Barn Climate}

Outdoor daily average ambient temperature with minima and maxima, outdoor humidity, and outdoor and indoor THI are illustrated in Figure 1. The THI was generally $5.1 \pm 0.8$ (mean $\pm \mathrm{SD}$ ) units higher indoors compared with outdoors. The average daily THI was $57.9 \pm 5.5$ outdoors and $62.7 \pm 5.1$ indoors. Periods of mild heat were measured in wk 5 and between wk 7 and 8, with average daily THI between 65 and 70 outdoors and 65 and 75 indoors.

\section{Feed Composition}

The chemical composition of the TMR, concentrates, and pasture are indicated in Table 2. Chemical composition of the pasture varied considerably during the experimental period, with an average DM content of 
$183 \pm 14 \mathrm{~g} / \mathrm{kg}$ (mean $\pm \mathrm{SD}$ ), CP content of $193 \pm 21 \mathrm{~g} /$ $\mathrm{kg}$ of DM, sugar content of $113 \pm 32 \mathrm{~g} / \mathrm{kg}$ of DM, and crude fiber content of $216 \pm 8 \mathrm{~g} / \mathrm{kg}$ of DM. In wk 7 and 10, the highest sugar (174 and $148 \mathrm{~g} / \mathrm{kg}$ ) and lowest CP contents (159 and $167 \mathrm{~g} / \mathrm{kg}$ ) were observed.

\section{Pasture Measurements}

The average pasture height was $6.6 \pm 0.7 \mathrm{~cm}$ (mean \pm SD) and daily pasture allowances were: $24.2 \pm 2.2$ for wk 5 and $6,23.8 \pm 4.3$ for wk 7 and 8 , and $16.5 \pm 4.5 \mathrm{~kg}$ of DM/cow per day for wk 9 and 10 (means \pm SEM). Pasture 1 consisted of (estimated pasture coverage; mean \pm SD) $80.2 \pm 13.8 \%$ perennial ryegrass (Lolium perenne), $7.8 \pm 11.6 \%$ shepherd's purse (Capsella bursapastoris), $6.6 \pm 1.1 \%$ timothy-grass (Phleum pratense), $2.0 \pm 1.9 \%$ meadow fescue (Festuca pratensis), $1.0 \pm$ $1.3 \%$ Kentucky bluegrass (Poa pratensis), $0.6 \pm 0.4 \%$ annual meadow grass (Poa annua), $0.5 \pm 0.4 \%$ common chickenweed (Stellaria media), $0.4 \pm 0.8 \%$ white clover (Trifolium repens), $0.2 \pm 0.4 \%$ red fescue (Festuca rubra), $0.2 \pm 0.4 \%$ common dandelion (Taraxacum officinale), $0.1 \pm 0.1 \%$ couch grass (Elymus repens), $0.1 \pm 0.1 \%$ purple deadnettle (Lamium purpureum), and $0.1 \pm 0.1 \%$ cut-leaved Crane's-bill (Geranium dissectum). Pasture 2 consisted of $60.0 \pm 5.3 \%$ perennial ryegrass, $22.0 \pm 10.3 \%$ meadow fescue, $10.0 \pm 5.4 \%$ timothy-grass, $0.2 \pm 0.1 \%$ common chickenweed, and $0.2 \pm 0.0 \%$ common dandelion.

\section{Animal Measurements}

DMI. The average DMI from TMR and pasture and concentrate, as well as in barn water intake, are illustrated in Figure 2. The average DMI from TMR of the $\mathrm{CG}$ was $18.1 \pm 0.3 \mathrm{~kg}$ of $\mathrm{DM} /$ cow per day and exhibited only small fluctuations throughout the trial. The average water intake of the CG was $61.2 \pm 1.9 \mathrm{~kg} /$ cow per day and correlated significantly with THI ( $\mathrm{r}$ $=0.90 ; P<0.001)$. The DMI from TMR and in barn water intake in the PG gradually declined in the first 4 wk due to partial pasture access during wk 2 to 4 . The estimated DMI using the n-alkane method in wk 7 and 9 showed a significant difference between groups and an increase between wk $7(12.7 \pm 0.3 \mathrm{DM} /$ cow per day $)$ and $9(15.0 \pm 0.3 \mathrm{DM} /$ cow per day) within the PG. The estimated DMI using the exclosure cage method also indicated an increase in DMI between wk 5 and 6 as well as wk 7 and 8 , but accounted for a much higher intake compared with the n-alkane method: $16.8 \pm 1.5$ in wk 5 and $6,21.5 \pm 3.2$ in wk 7 and 8 , and $22.2 \pm 6.1$ $\mathrm{kg}$ of DM/cow per day in wk 9 and 10 (means \pm SEM).

Milk Yield and Composition. Milk yield and protein and fat content are illustrated in Figure 3. For milk, protein, fat, and lactose yield a group $(\mathbf{G})$, time $(\mathbf{T})$, and group by time $(\mathbf{G x T})$ effect was observed (protein yield $=P_{\mathrm{G}}<0.01, P_{\mathrm{T}}<0.001, P_{\mathrm{GxT}}<0.001$ fat yield $=P_{\mathrm{G}}<0.001, P_{\mathrm{T}}<0.001, P_{\mathrm{GxT}}<0.001$ lactose yield $=P_{\mathrm{G}}<0.01, P_{\mathrm{T}}<0.001 ; P_{\mathrm{GxT}}<0.001$

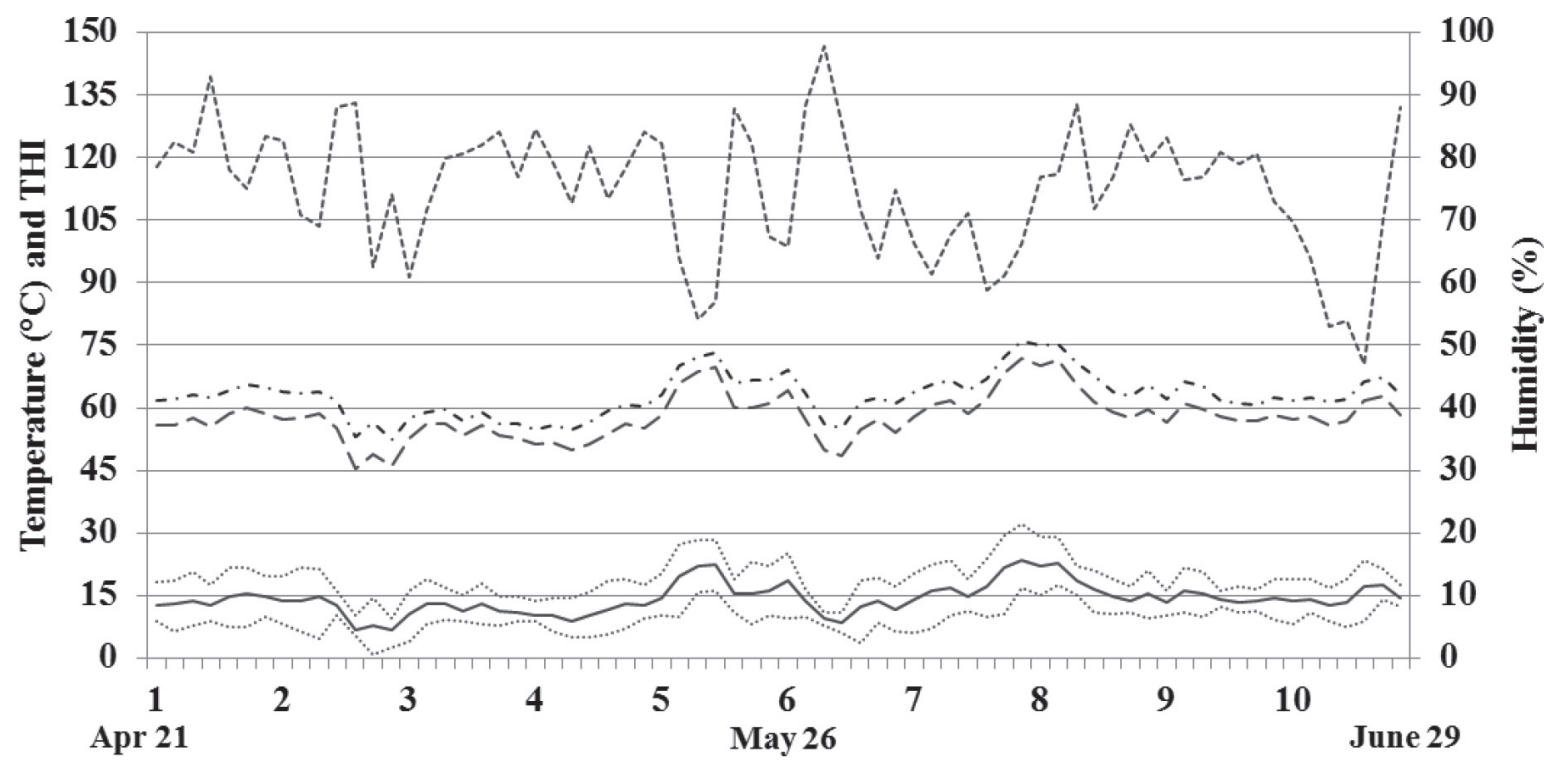

Week and Timeline

Figure 1. Outdoor daily average ambient temperature (solid line) with minima and maxima (dotted lines), outdoor humidity (short dashed line), outdoor temperature-humidity index (THI; long dashed line), and indoor THI (dash-dot line). THI calculated according to Hahn (1999); $\mathrm{THI}=0.8 \mathrm{td}+$ relative humidity $\times(\mathrm{td}-14.4)+46.4$, where $\mathrm{td}=$ dry bulb temperature $\left({ }^{\circ} \mathrm{C}\right)$. 


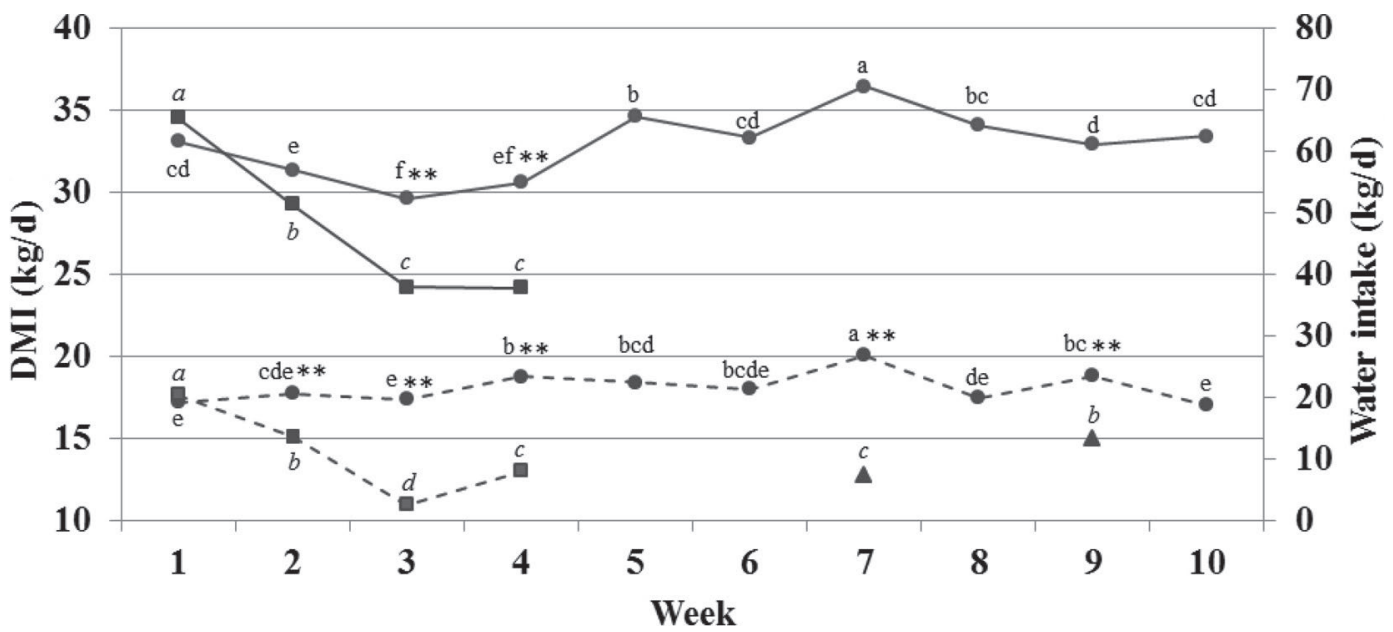

Figure 2. Effect of a ration change from TMR to pasture on DMI and water intake. Dashed line $=$ DMI from TMR; $\boldsymbol{\Delta}=$ DMI from pasture $(\mathrm{PG})$ estimated using the n-alkane method (pooled SEM $=0.3)$; solid line $=$ water intake recorded in barn $($ pooled SEM $=1.9)$; $\bullet$ confinement group $(\mathrm{CG}, \mathrm{n}=31) ; \boldsymbol{\square}=$ pasture group $(\mathrm{PG}, \mathrm{n}=29)$. Significance: $\mathrm{DMI}=\operatorname{group}(\mathrm{G}): P<0.001$, time $(\mathrm{T}): P<0.001, \mathrm{G} \times \mathrm{T}: P<0.001$; water intake $=\mathrm{G}: P<0.01, \mathrm{~T}: P<0.001, \mathrm{G} \times \mathrm{T}: P<0.001$. Two asterisks $(* *)$ indicate significant differences between groups in particular week $(P \leq 0.01)$; different letters $(\mathrm{a}-\mathrm{e})$ indicate significant differences between weeks within particular groups $(P \leq 0.05)$. The CG stayed on a TMR-based diet during the entire trial, whereas the PG was slowly introduced to a pasture-based ration: wk $1=$ TMR, wk $2=$ TMR and $3 \mathrm{~h}$ of pasture/d, wk 3 and $4=\mathrm{TMR}$ and $12 \mathrm{~h}$ of pasture/d, wk $5-10=$ pasture and $1.75 \mathrm{~kg}$ of DM concentrate/d.

data for protein, fat, and lactose yield not shown). Milk production decreased in the PG in the first week on a full grazing ration and significant differences between the groups were present during wk 5 to 7 . Due to a decrease in milk production in the $\mathrm{CG}$, no difference between groups was present in wk 8 to 10 .

Milk fat content remained uninfluenced by treatment until wk 4. In wk 5, the PG exhibited a significantly lower fat content compared with the CG. Starting from wk 7, the milk fat content of the CG slightly increased whereas the opposite was observed for the PG, resulting in significant interactions between week and group and significant group differences in wk 9 and 10. Milk fat content exhibited a group as well as time effect, and a significant effect of the group by time interaction was noted. A significantly lower milk fat content in the PG

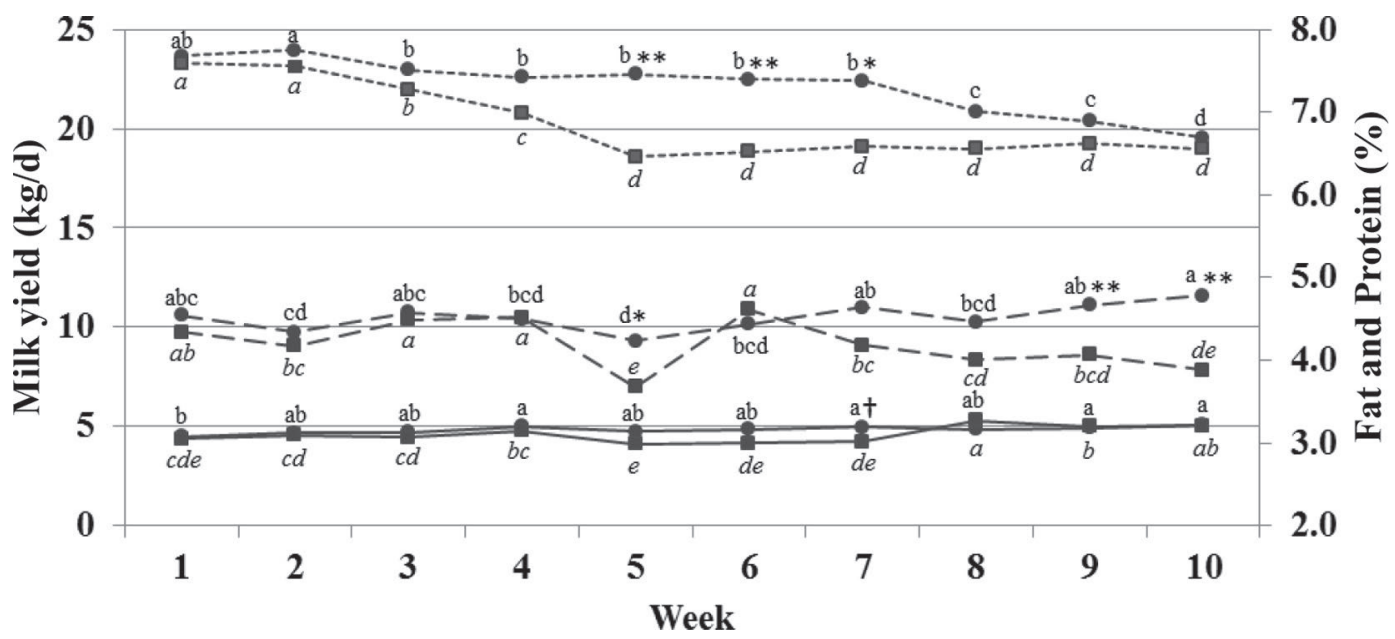

Figure 3. Effect of a ration change from TMR to pasture on milk yield (short dashed line; pooled SEM = 0.6), fat \% (long dashed line; pooled SEM $=0.10)$, and protein $\%($ solid line; pooled SEM $=0.03) ; \boldsymbol{\bullet}=$ confinement group $(\mathrm{CG}, \mathrm{n}=31) ; \mathbf{\square}=$ pasture group $(\mathrm{PG}, \mathrm{n}=29)$. Significance: milk yield $=$ group $(\mathrm{G}): P<0.05$, time $(\mathrm{T}): P<0.001, \mathrm{G} \times \mathrm{T}: P<0.001$; fat $\%=\mathrm{G}: P=0.01, \mathrm{~T}: P<0.001, \mathrm{G} \times \mathrm{T}: P<0.001$; protein $\%=$ G: nonsignificiant, T: $P<0.001, \mathrm{G} \times \mathrm{T}: P<0.001$. Different symbols indicate significant differences between groups in particular week $\left(\dagger P \leq 0.10\right.$; ${ }^{*} P \leq 0.05$; $\left.* * P \leq 0.01\right)$; different letters $(\mathrm{a}-\mathrm{d})$ indicate significant differences between weeks within particular groups $(P \leq$ 0.05). The CG stayed on a TMR-based diet during the entire trial, whereas the PG was slowly introduced to a pasture-based ration: wk $1=$ TMR, wk $2=$ TMR and $3 \mathrm{~h}$ of pasture/d, wk 3 and $4=$ TMR and $12 \mathrm{~h}$ of pasture/d, wk $5-10=$ pasture and $1.75 \mathrm{~kg}$ of DM concentrate/d. 


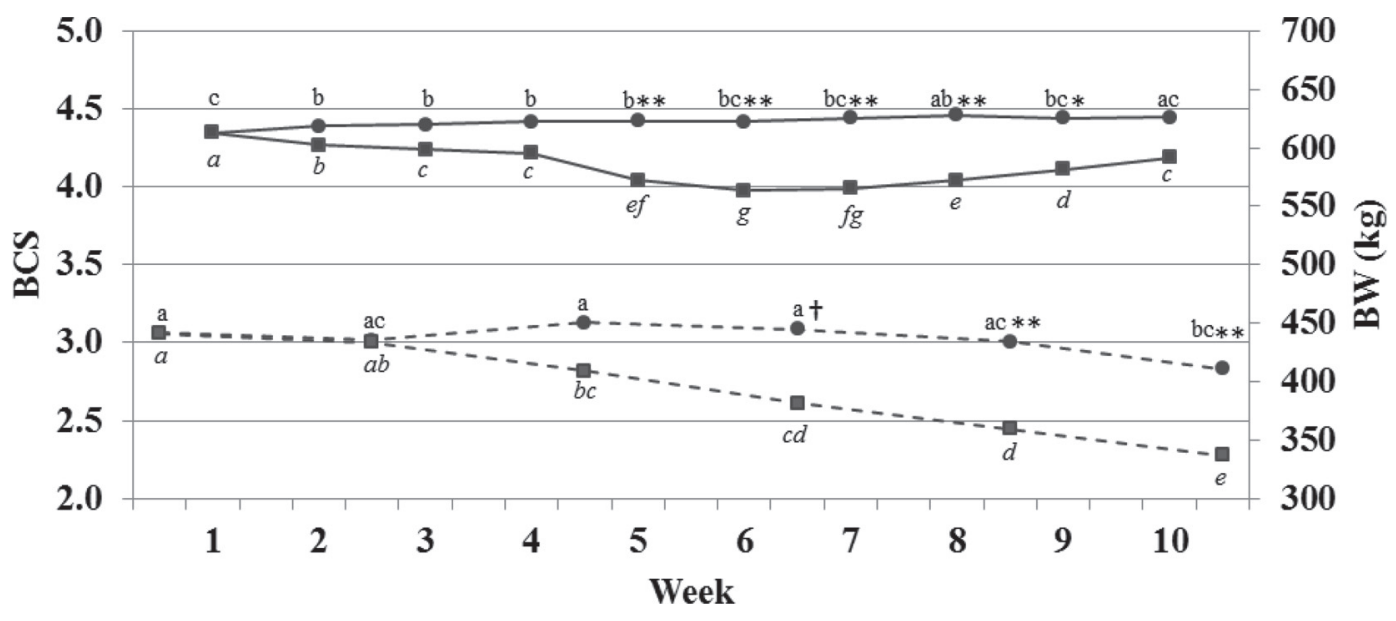

Figure 4. Effect of a ration change from TMR to pasture on BW (solid line; pooled SEM = 8) and BCS (dashed line; pooled SEM =0.11). Body weight was assessed daily and a weekly mean was calculated per cow; BCS was assessed at the beginning of the week in 14-d intervals. $=$ confinement group $(\mathrm{CG}, \mathrm{n}=31) ; \mathbf{\square}=$ pasture group $(\mathrm{PG}, \mathrm{n}=29)$. Significance: $\mathrm{BCS}=$ group $(\mathrm{G}): P<0.05$, time $(\mathrm{T}): P<0.001, \mathrm{G} \times \mathrm{T}$ : $P<0.001 ; \mathrm{BW}=\mathrm{G}: P<0.01, \mathrm{~T}: P<0.001, \mathrm{G} \times \mathrm{T}: P<0.001$. Different symbols indicate significant differences between groups in particular week $\left(\dagger P \leq 0.10 ; * P \leq 0.05 ;{ }^{* *} P \leq 0.01\right)$; different letters $(\mathrm{a}-\mathrm{g})$ indicate significant differences between weeks within particular groups $(P \leq$ 0.05). The CG stayed on a TMR-based diet during the entire trial, whereas the PG was slowly introduced to a pasture-based ration: wk $1=$ TMR, wk $2=$ TMR and $3 \mathrm{~h}$ of pasture/d, wk 3 and $4=$ TMR and $12 \mathrm{~h}$ of pasture/d, wk $5-10=$ pasture and $1.75 \mathrm{~kg}$ of DM concentrate/d.

was observed in wk 5,9, and 10 compared with the CG. Milk protein content exhibited a significant time and group by time effect in the PG and a tendency for lower milk protein content was observed in wk 7 . Milk lactose content exhibited a time and a time by group effect $\left(P_{\mathrm{G}}=\right.$ nonsignificant, $P_{\mathrm{T}}<0.001, P_{\mathrm{GxT}}<0.001$; data not shown). Milk lactose content continuously decreased in the PG from wk 5 and in the CG from wk 6 . No significant differences were present between groups at corresponding time points. Milk urea content $(\mathrm{mg} / \mathrm{kg})$ was influenced by a time, group as well as a significant group and time interaction $\left(P_{\mathrm{G}}<0.001, P_{\mathrm{T}}\right.$ $<0.001, P_{\mathrm{GxT}}<0.001$; data not shown). Average milk urea content was $155 \pm 17 \mathrm{mg} / \mathrm{kg}$ (means $\pm \mathrm{SD}$ ) in the $\mathrm{CG}$ and exhibited only small fluctuations across the trial. In the PG milk, urea content started increasing in wk 3 (wk $1=172$, wk $2=182$, wk $3=173$, wk 4 $=190$, wk $5=270$, wk $6=268$, wk $7=178$, wk $8=$ 408 , wk $9=286$, wk $10=225 \mathrm{mg} / \mathrm{kg}$; PSEM $=6$ ). A tendency was observed in wk $3(P<0.06)$ and a significant difference between groups was present in wk 4 to $6(P<0.001)$ and 8 to $10(P<0.001)$. A tendency for a correlation of milk urea content with pasture $\mathrm{CP}$ content was observed ( $\mathrm{r}=0.81 ; P=0.09)$. No group, time, or group by time effect was observed for SCC (data not shown).

$\boldsymbol{B} \boldsymbol{W}$ and $\boldsymbol{B} \boldsymbol{C S}$. Body weight as well as BCS was influenced by group, time, as well as a group by time interaction (Figure 4). The BW of the CG exhibited an increase of $15 \pm 16 \mathrm{~kg}$ (means $\pm \mathrm{SD}$ ) between wk 1 and
8. The $\mathrm{BW}$ of the $\mathrm{PG}$ decreased by $48 \pm 22 \mathrm{~kg}$ from wk 1 until 7 , and thereafter increased again until wk 10 by $26 \pm 10 \mathrm{~kg}$. The PG lost, on average, $0.18 \pm 0.02$ BCS units per $14 \mathrm{~d}$ from wk 3 on. The CG increased slightly in BCS in the first half but lost $0.3 \pm 0.3 \mathrm{BCS}$, on average, in the second half of the trial.

Blood. Results of complete blood counts are illustrated in Table 3. Total white blood cell, lymphocyte, and granulocyte concentrations exhibited a significant group by time interaction due to a decrease in the CG in wk 9 and 10. No significant group, time, or group by time interaction effects were observed for monocyte concentration. For the eosinophil concentration, only a time effect was observed, no group effect or group by time interaction was noted. Red blood cell count exhibited a divergence between groups in red blood cells (RBC), hemoglobin (HGB), and hematocrit (HCT) from wk 5 on. In wk 5 to $10, \mathrm{RBC}, \mathrm{HGB}$, and HCT were numerically higher in the PG compared with the CG. A significant difference between groups was observed for HGB and RBC in wk 9, and for HCT in wk 5, 6, 7, and 9. In the CG, a decrease in RBC, HGB, and HCT was observed in wk7 to $9\left(\mathrm{RBC}=P_{\mathrm{GxT}}<0.001 ; \mathrm{HGB}=\right.$ $\left.P_{\mathrm{GxT}}<0.10 ; \mathrm{HCT}=P_{\mathrm{GxT}}=0.01\right)$. The mean corpuscular volume (MCV) decreased continuously from wk 1 to 10 in the CG. In the PG, the MCV decreased from wk 1 to 7 and increased in wk 8 to $10\left(P_{\mathrm{GxT}}<0.001\right)$. No significant difference between groups was observed for mean corpuscular hemoglobin (MCH) at any time during the trial. In the $\mathrm{CG}, \mathrm{MCH}$ decreased in wk 8 
to 10 contributed to a significant group by time interaction. Mean corpuscular hemoglobin concentrations (MCHC) were higher in the PG compared with the CG in wk 1 and 3. Between wk 4 and 10 no significant changes occurred in the PG. In the $\mathrm{CG}$ an increase from wk 5 until 7, with a subsequent decrease until wk 9 was observed. In wk 7 a tendency for a higher $\mathrm{MCHC}$ was observed in the CG compared with the PG $\left(P_{\mathrm{GxT}}<\right.$ 0.001). Red blood cell distribution width (RDW) did not exhibit any significant differences between groups at any time, but a group by time interaction due to an increase in the PG in wk 7 to 10 . No significant changes in RDW were observed in the CG. Platelet distribution width (PDW) showed similar development in wk 1 to 5 in the PG and CG. In wk 6 and 8, PDW was higher in the PG $\left(P_{\mathrm{GxT}}<0.001\right)$.

Clinical chemistry variables are illustrated in Table 4 and Figures $5-7$. The group by time interaction was significant for albumin concentration, as the values measured for the PG decreased from wk 6 to 10 after an initial increase whereas the corresponding concentrations of CG increased steadily over time. For serum total protein concentrations, a time effect was observed due to a decrease from wk 1 to 6 in both groups. But no group or group by time interactions were observed. Serum BHB concentrations exhibited a group, time, and group by time effect and were significantly higher in wk 7, 9, and $10(1.02 \pm 0.04 \mathrm{mmol} / \mathrm{L}$; means $\pm \mathrm{SD})$ in the PG compared with wk $1(0.68 \pm 0.04 \mathrm{mmol} / \mathrm{L}$; $P<0.05)$; a significant difference between groups was only observed in wk 9 (Figure 5). Serum glucose concentrations were influenced by a significant time as well as a group by time interaction. An increase in both groups from wk 1 to 4 (from 55.8 to $62.3 \pm 1.5 \mathrm{mg} / \mathrm{dL}$ ), a subsequent decrease until wk $8(44.5 \pm 1.5 \mathrm{mg} / \mathrm{dL})$, followed by an increase at wk 9 and $10(56.5 \pm 1.5 \mathrm{mg} /$ $\left.\mathrm{dL} ; P_{\mathrm{GxT}}<0.001\right)$ was observed. Groups did not differ significantly at any time during the trial. Serum glucose correlated positively with THI $(\mathrm{r}=0.55 ; P=0.01)$ and serum BHB concentrations $(\mathrm{r}=0.45 ; P<0.05)$. For serum fatty acids as well as triglyceride concentrations, a group, time, and group by time effect was observed (Figure 6). Serum fatty acids concentrations increased in the $\mathrm{PG}$ from 0.23 to $0.42 \pm 0.02 \mathrm{mmol} / \mathrm{L}$ in wk 3 and 8 , respectively; thereafter, a decrease to $0.39 \pm 0.02$ $\mathrm{mmol} / \mathrm{L}$ in wk 10 was observed. A significant difference between groups was observed in wk 4 and 6 to 9 . Concurrent to increased serum fatty acids concentrations, a significant increase in serum triglyceride concentrations was measured in the PG during the full grazing period (wk 6 and 10). In CG, the serum triglyceride concentrations increased as well, but not as high as in the PG, causing a significant group by time interaction. A significant difference between groups was present in wk 6 and 10. Serum cholesterol concentrations exhibited a group, time, and group by time effect. No significant alterations were observed within the CG. In PG, a decrease from wk 6 to 10 contributed to a significant difference between groups at that point in time. Serum AST concentrations were generally higher in the PG; therefore, a significant group effect was observed. In wk 6 a tendency for lower serum AST concentrations were observed in the PG compared with wk $1(P<$ 0.10). A significant increase in the $P G$ as well as $C G$ was observed from wk 6 to 10 causing a significant time effect. No group by time interaction was present. Serum $\gamma$-GT concentrations were not altered in the CG over the course of the trial. In the PG a decrease over the course of the trial was observed, contributing to significant group, time, and group by time effects. In wk 6 a tendency and in wk 10 significantly lower serum $\gamma$-GT concentrations were observed in the PG. No change was observed in serum bilirubin concentrations within the PG over the course of the trial. Within the $\mathrm{CG}$ an increase was observed in wk 6 , leading to a significant difference between groups at that point in time and a significant time and group by time effect. Serum GLDH activities were not influenced at any time by group, time, or group by time effects. Serum urea concentrations exhibited a group, time, and group by time effect and are depicted together with urine total N-tocreatinine ratio in Figure 7. Serum urea concentrations increased continuously in the PG from wk 3 on (except for wh 5 and 7 ). In the CG, plasma urea levels were elevated in wk 8 to 10 . A significant difference between groups for serum urea concentrations were observed in wk 4, 6, 9, and 10. Serum urea concentrations did not correlate significantly with pasture $\mathrm{CP}$ content.

Urine. Urine creatinine concentrations and purine derivatives (PD; allantoin and uric acid)-to-creatinine ratios are summarized in Figure 8. Both variables exhibited a group, time, as well as group by time effect. Creatinine concentration decreased in the PG as soon as the animals were on a full-pasture ration. In the $\mathrm{CG}$, a decrease in creatinine concentrations in the urine was observed during wk 6 to 8 . A significant difference between groups was observed in wk 5 to 6 and 8 to 10 . Urine creatinine concentrations correlated positively with water intake $(\mathrm{r}=0.25 ; P<0.001)$ in the $\mathrm{CG}$. A significantly higher PD-to-creatinine ratio was observed in the PG in wk 9 and 10. Urine total N-to-creatinine ratio was influenced by a group and time effect, as well as a group by time interaction (illustrated in Figure 7), and indicates an increase in $\mathrm{N}$ elimination via urine in the PG compared with the CG. Significant differences between groups were observed in wk 4 and 10. In wk 7 , 


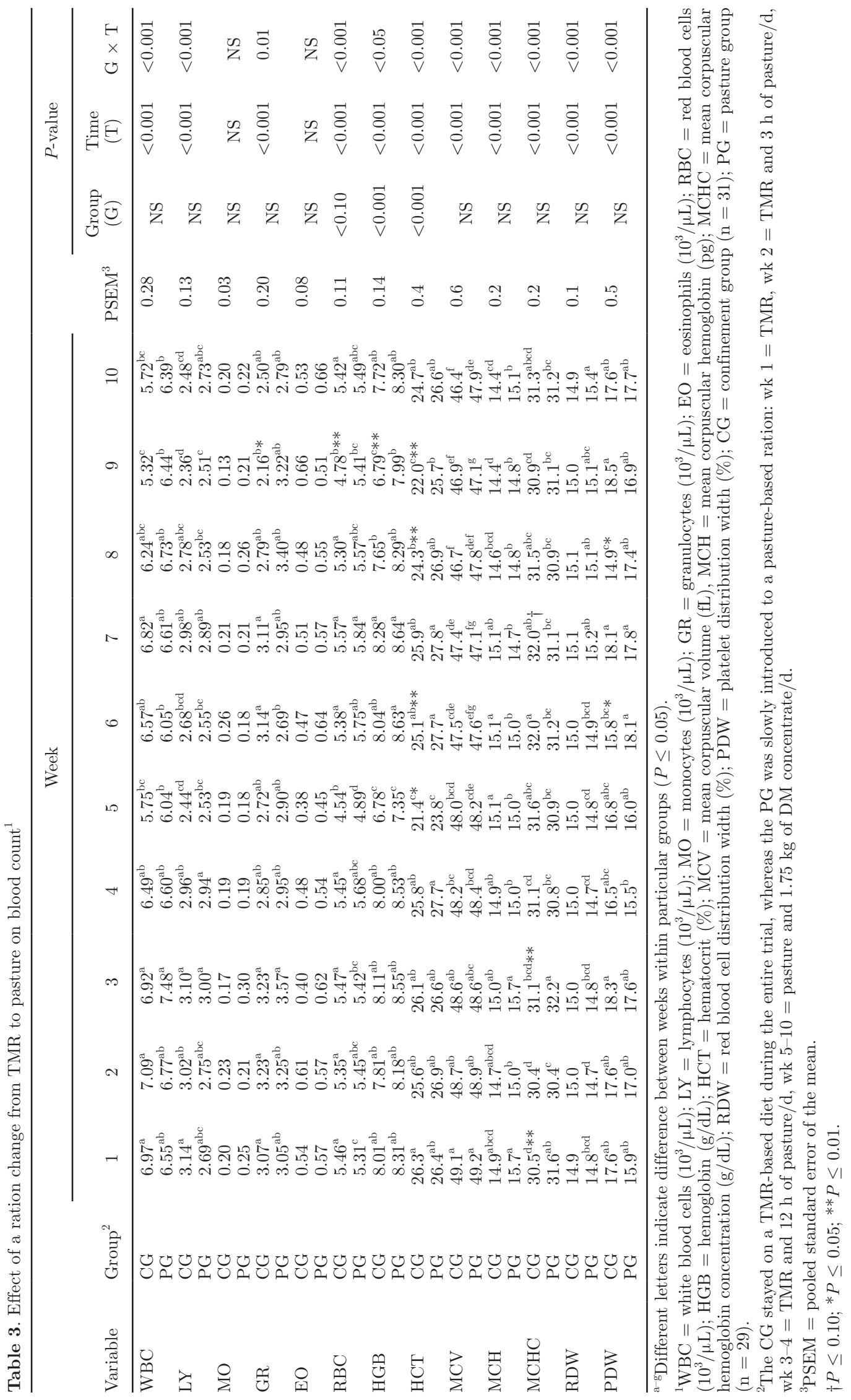




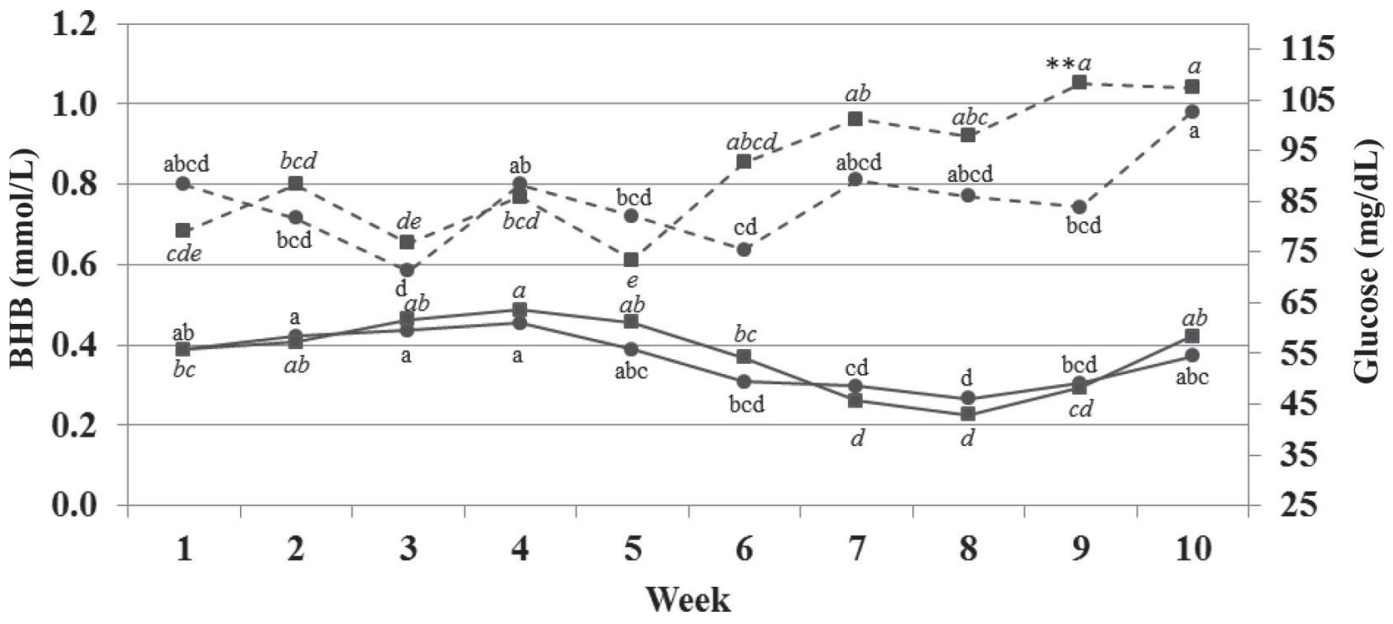

Figure 5. Effect of a ration change from TMR to pasture on serum glucose (solid line; pooled SEM = 1.5) and BHB (dashed line; pooled $\mathrm{SEM}=0.04)$ concentrations; - confinement group $(\mathrm{CG}, \mathrm{n}=31) ; \boldsymbol{\square}=$ pasture group $(\mathrm{PG}, \mathrm{n}=29)$. Significance: $\mathrm{BHB}=\operatorname{group}(\mathrm{G}): P<0.01$, time (T): $P<0.001, \mathrm{G} \times \mathrm{T}: P<0.001 ;$ glucose $=\mathrm{G}: P<0.10, \mathrm{~T}: P<0.001, \mathrm{G} \times \mathrm{T}: P<0.01$. Asterisks $(* *)$ indicate significant differences between groups in particular week $(P \leq 0.01)$; different letters $(\mathrm{a}-\mathrm{e})$ indicate significant differences between weeks within particular groups $(P$ $\leq 0.05$ ). The CG stayed on a TMR-based diet during the entire trial, whereas the PG was slowly introduced to a pasture-based ration: wk 1 $=\mathrm{TMR}$, wk $2=\mathrm{TMR}$ and $3 \mathrm{~h}$ of pasture $/ \mathrm{d}$, wk 3 and $4=\mathrm{TMR}$ and $12 \mathrm{~h}$ of pasture $/ \mathrm{d}$, wk $5-10=$ pasture and $1.75 \mathrm{~kg}$ of DM concentrate/d.

in the $\mathrm{CG}$ as well as the $\mathrm{PG}$, an almost 2 fold increase in the urine total N-to-creatinine ratio and urine PD-tocreatinine ratio was observed. Urine $\mathrm{pH}$ was influenced by a group, time, and group by time effect $\left(P_{\mathrm{G}}<0.001\right.$, $P_{\mathrm{T}}<0.001, P_{\mathrm{GxT}}<0.001 ;$ data not shown). In the CG, no significant changes in urine $\mathrm{pH}$ were observed (8.01 \pm 0.06 ; means $\pm \mathrm{SD}$ ). Urine $\mathrm{pH}$ of the $\mathrm{PG}$ decreased continuously from wk 4 to 9 and a significant difference between groups was observed in wk 8 to 10 (wk $8=7.7$, wk $9=7.39$, wk $10=7.6 ; P<0.001 ;$ PSEM $=0.04)$.

\section{DISCUSSION}

The main cow-associated difference in a TMR compared with a pasture-based system lies in the possible DMI, the ration composition, and the energy demand. Dry matter intake is limited to approximately $20 \mathrm{~kg}$ of $\mathrm{DM} / \mathrm{d}$ and pasture-based rations are lower in $\mathrm{ME}$ content (Kolver, 2003). Further, the form of feed acquisition (grazing and walking) results in higher energy expenses compared with readily available feed such as

Table 4. Effect of a ration change from TMR to pasture on blood clinical chemistry variables ${ }^{1}$

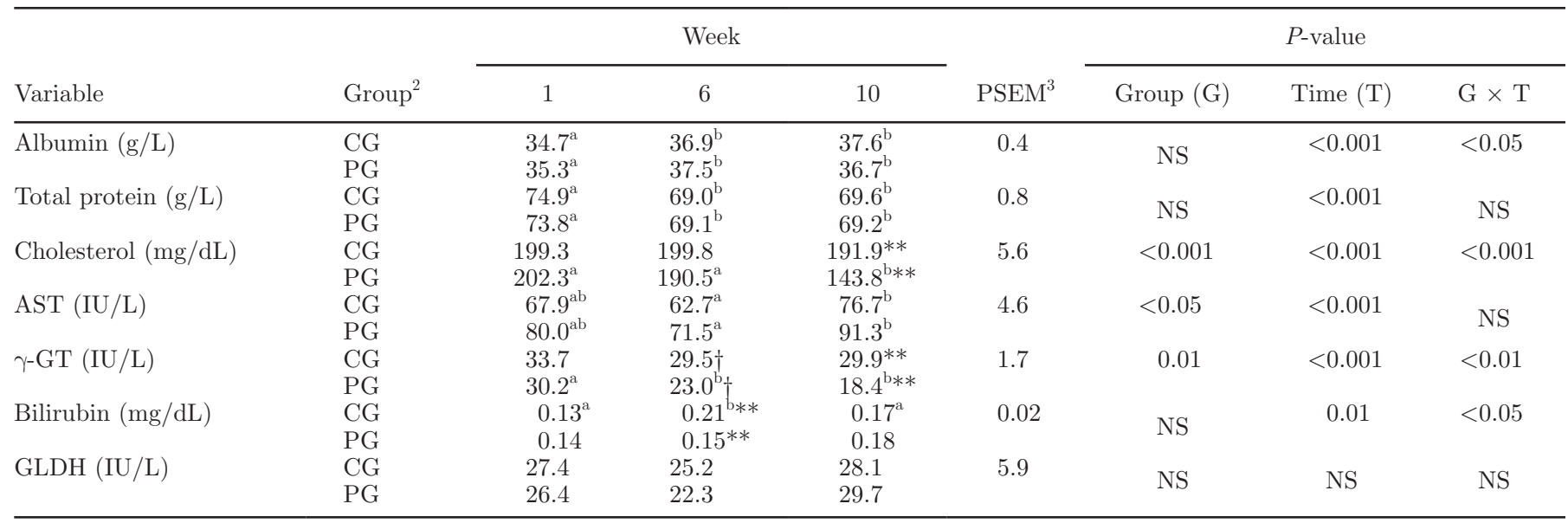

${ }^{\mathrm{a}, \mathrm{b}}$ Different letters indicate differences between weeks within particular groups $(P \leq 0.05)$.

${ }^{1} \gamma$-GT $=\gamma$-glutamyltransferase; GLDH $=$ glutamate dehydrogenase; $\mathrm{CG}=$ confinement group $(\mathrm{n}=31)$; PG $=$ pasture group $(\mathrm{n}=29)$.

${ }^{2}$ The CG stayed on a TMR-based diet during the entire trial, whereas the PG was slowly introduced to a pasture-based ration: wk $1=$ TMR, wk $2=$ TMR and $3 \mathrm{~h}$ of pasture/d, wk $3-4=$ TMR and $12 \mathrm{~h}$ of pasture/d, wk 5-10 = pasture and $1.75 \mathrm{~kg}$ of DM concentrate/d.

${ }^{3} \mathrm{PSEM}=$ pooled standard error of the mean

$\dagger P \leq 0.10$; ${ }^{* *} P \leq 0.01$. 


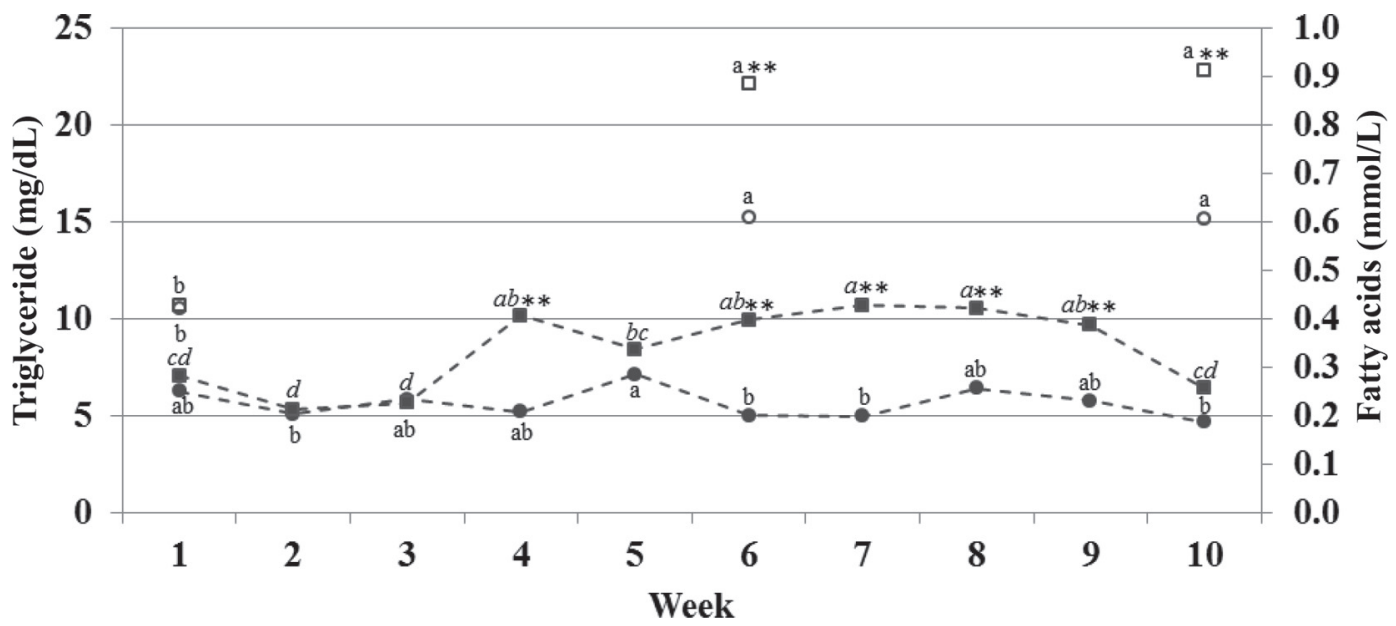

Figure 6. Effect of a ration change from TMR to pasture on serum triglyceride (no line; pooled SEM =0.6) and fatty acids (dashed line; pooled SEM $=0.02)$ concentrations. Circles $=$ confinement group $(\mathrm{CG}, \mathrm{n}=31)$; squares $=$ pasture group $(\mathrm{PG}, \mathrm{n}=29)$. Significance: triglyceride $=\operatorname{group}(\mathrm{G}): P<0.001$, time $(\mathrm{T}): P<0.001, \mathrm{G} \times \mathrm{T}: P<0.001$; fatty acids $=\mathrm{G}: P<0.001$, T: $P<0.001, \mathrm{G} \times \mathrm{T}: P<0.001$. Asterisks $(* *)$ indicate significant differences between groups in particular week $(P \leq 0.01)$; different letters $(\mathrm{a}-\mathrm{d})$ indicate significant differences between weeks within particular groups $(P \leq 0.05)$. The CG stayed on a TMR-based diet during the entire trial, whereas the PG was slowly introduced to a pasture-based ration: wk $1=$ TMR, wk $2=$ TMR and $3 \mathrm{~h}$ of pasture/d, wk 3 and $4=$ TMR and $12 \mathrm{~h}$ of pasture/d, wk $5-10=$ pasture and $1.75 \mathrm{~kg}$ of DM concentrate/d.

a TMR (Osuji, 1974; Kolver, 2003; Roca-Fernandez et al., 2013). Therefore, it is not surprising that during this trial substantial changes were observed in the PG regarding DMI, body condition, milk production, and energy metabolites. Due to a partial access of the PG to pasture in wk 2 to 4 we observed a decrease in DMI from TMR over the first $4 \mathrm{wk}$ of the trial. A decrease in $\mathrm{BW}, \mathrm{BCS}$, and milk production indicates that a lower TMR intake and a higher energy demand due to grazing activity were not compensated by an adapted intake from pasture. This proposition is supported by the study of Bargo et al. (2002), who described a lower milk production and DMI in a feeding system combining TMR and pasture compared with TMR only. When

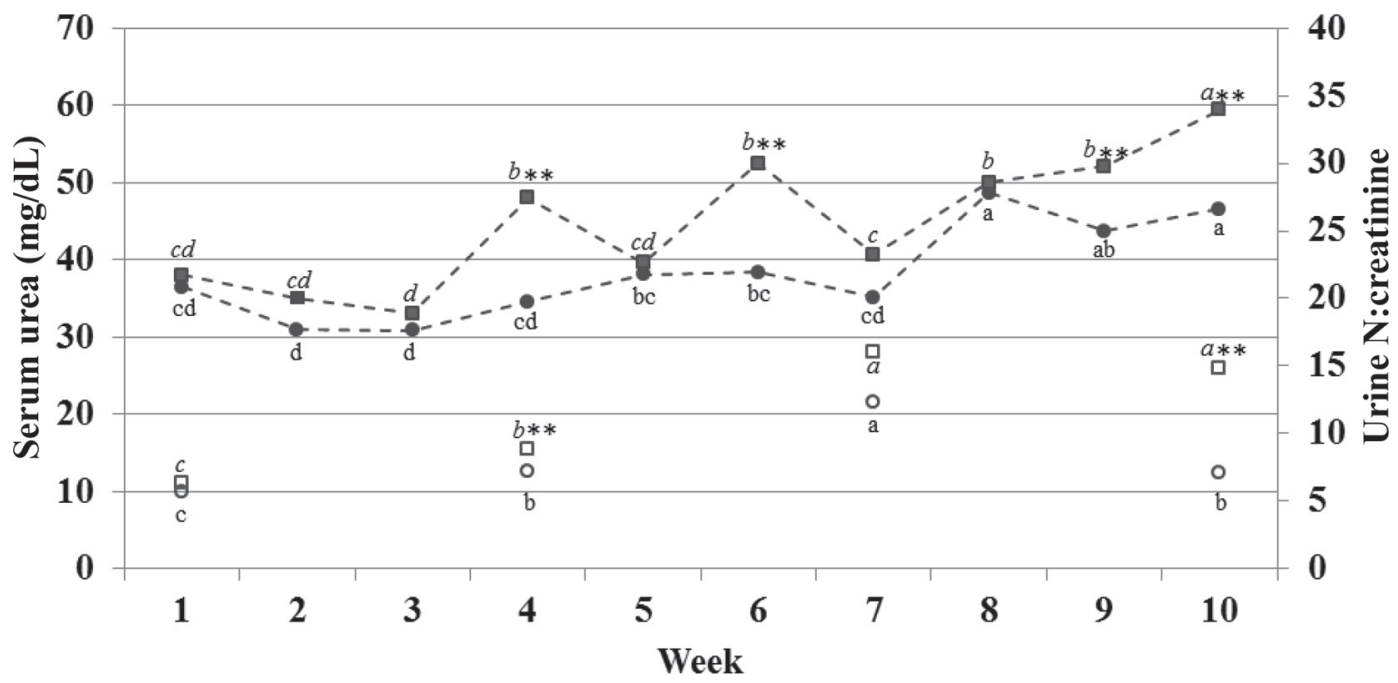

Figure 7. Effect of a ration change from TMR to pasture on serum urea concentration (dashed line; pooled SEM = 1.4) and urine N-tocreatinine ratio (no line; pooled SEM $=0.5$ ). Circles $=$ confinement group $(\mathrm{CG}, \mathrm{n}=31$ ); squares $=$ pasture group $(\mathrm{PG}, \mathrm{n}=29)$. Significance: serum urea $=\operatorname{group}(\mathrm{G}): P<0.001$, time $(\mathrm{T}): P<0.001, \mathrm{G} \times \mathrm{T}: P<0.001 ;$ urine N-to-creatinine $=\mathrm{G}: P<0.001, \mathrm{~T}: P<0.001, \mathrm{G} \times \mathrm{T}: P$ $<0.001$. Asterisks $(* *)$ indicate significant differences between groups in particular week $(P \leq 0.01)$; different letters (a-d) indicate significant differences between weeks within particular groups $(P \leq 0.05)$. The CG stayed on a TMR-based diet during the entire trial, whereas the PG was slowly introduced to a pasture-based ration: wk $1=\mathrm{TMR}$, wk $2=\mathrm{TMR}$ and $3 \mathrm{~h}$ of pasture/d, wk 3 and $4=\mathrm{TMR}$ and $12 \mathrm{~h}$ of pasture/d, wk $5-10=$ pasture and $1.75 \mathrm{~kg}$ of DM concentrate $/ \mathrm{d}$. 


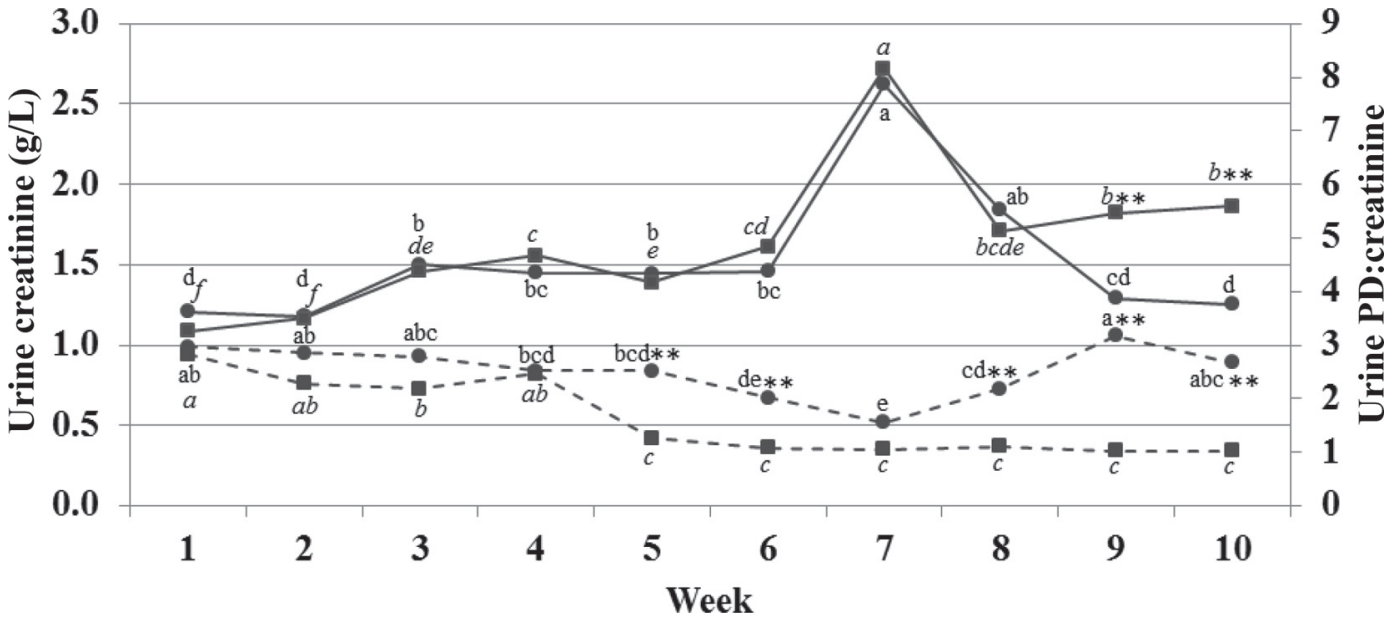

Figure 8. Effect of a ration change from TMR to pasture on urine creatinine concentrations (dashed line; pooled SEM $=0.05$ ) and urine purine derivatives $(\mathrm{PD})$-to-creatinine ratio (solid line; pooled SEM = 0.20); $\bullet=$ confinement group $(\mathrm{CG}, \mathrm{n}=31$ ); $\boldsymbol{\square}=$ pasture group $(\mathrm{PG}, \mathrm{n}$ $=29)$. Significance: urine creatinine $=$ group $(\mathrm{G}): P<0.001$, time $(\mathrm{T}): P<0.001, \mathrm{G} \times \mathrm{T}: P<0.001 ;$ urine $\mathrm{PD}$-to-creatinine $=\mathrm{G}: P<0.05$, $\mathrm{T}: P<0.001, \mathrm{G} \times \mathrm{T}: P<0.001$. Asterisks $(* *)$ indicate significant differences between groups in particular week $(P \leq 0.01)$; different letters (a-f) indicate significant differences between weeks within particular groups $(P \leq 0.05)$. The CG stayed on a TMR-based diet during the entire trial, whereas the PG was slowly introduced to a pasture-based ration: wk $1=$ TMR, wk $2=\mathrm{TMR}$ and $3 \mathrm{~h}$ of pasture/d, wk 3 and $4=\mathrm{TMR}$ and $12 \mathrm{~h}$ of pasture/d, wk $5-10=$ pasture and $1.75 \mathrm{~kg}$ of DM concentrate $/ \mathrm{d}$.

the PG switched completely onto a full grazing ration in wk 5, milk production and BW dropped significantly, indicating a further decrease in DMI. The continuous decrease in BCS, an increased milk fat content in wk 6 and decreased serum glucose concentrations, and increased serum BHB and fatty acids concentrations in wk 6 to 9 clearly suggest that during the first weeks on pasture an energy deficit was present and lipomobilization occurred. This is supported by several studies that have observed a lower BCS (Washburn et al., 2002; Fontaneli et al., 2005) and higher blood BHB and fatty acids concentrations (Kolver and Muller, 1998; Bargo et al., 2002) in cows in grazing compared with confinement systems. In grazing systems, cows of high-yielding breeds in particular are often supplemented with concentrates to counterbalance an energy deficit (Mayne et al., 2000; Bargo et al., 2003). Additionally, other management approaches, such as different grazing systems, are implemented to maximize DMI (Mayne et al., 2000). Further research is needed to investigate whether an appropriate supplementation or different grazing system would have attenuated the observed energy deficit.

To estimate DMI, the exclosure cage as well as the n-alkane method were employed. The exclosure cage method resulted in much higher DMI estimations compared with the n-alkane method. A difference in DMI of approximately $8 \mathrm{~kg}$ of DM indicates that, depending on the method used, enormous variation in DMI estimations are possible. Comparing milk yield, body condition, and blood metabolite data in this trial with the estimated DMI from the different methods we concluded that the exclosure cages most likely overestimated the DMI from pasture. To estimate the validity of the n-alkane method, the DMI to cover maintenance and milk production was calculated according to GfE (2001) guidelines [M. Schären U. Meyer, S. Dänicke (Friedrich-Loeffler-Institute, Brunswick, Germany), M. Bulang (Martin-Luther-University Halle-Wittenberg, Halle, Germany), unpublished data] and compared with the estimated DMI. A difference of $-1.6 \mathrm{~kg}$ of $\mathrm{DM} / \mathrm{d}$ in wk 7 and $0.3 \mathrm{~kg}$ of $\mathrm{DM} / \mathrm{d}$ in wk 9 was calculated by subtracting the calculated DMI (GfE, 2001) from the estimated DMI (n-alkane). As illustrated in the previous section, other traits measured during the trial suggest an energy deficit in the PG during the full grazing period. Combining this observation with the fact that the difference between the calculated DMI (GfE, 2001) and estimated DMI (n-alkane) was negative in wk 7 , we concluded that the n-alkane methods seems to be a fairly accurate method to estimate DMI from pasture. This observation is supported by other studies who have compared different techniques to estimate herbage intake (Reeves et al., 1996; Smit et al., 2005; reviewed in Decruyenaere et al., 2009).

As expected, the estimated DMI using the n-alkane method revealed a lower DMI in the PG compared with the CG in wk 7 and 9. The DMI estimates from both exclosure cages and n-alkane method show an increase in DMI from pasture from the first half (wk 5-7) to the second half of the full grazing period (wk8-10). In wk 1,5 , and 10 , we weighed the total rumen content 
of the rumen-fistulated cows and observed a decrease of $15 \mathrm{~kg}$ of rumen content between wk 1 and 5 and an increase of $20 \mathrm{~kg}$ in 10 compared with 5 in the PG [M. Schären U. Meyer, S. Dänicke (Friedrich-LoefflerInstitute, Brunswick, Germany), M. Bulang (MartinLuther-University Halle-Wittenberg, Halle, Germany), unpublished data]. This observation underlines that the sudden decrease and later increase of $\mathrm{BW}$ in the $\mathrm{PG}$ was separate from tissue mobilization due to a rapid decrease and later continuous increase of DMI. No further decreases in milk yield, a decrease in serum fatty acids concentrations, and an increase in BW to almost initial state in wk 10 in PG suggest that an adaption of grazing behavior led to a higher DMI and a decrease in energy deficit during this period. The further decrease in BCS and increased serum BHB concentrations $>1.00$ $\mathrm{mmol} / \mathrm{L}$, however, indicate that during this period tissue mobilization was still ongoing. At present, the functional interrelations between the variables serum BHB, fatty acids, and triglyceride concentrations as well as BCS during that period in PG cannot be elucidated. It might be concluded that the increased serum triglyceride and concurrently decreased serum fatty acids concentrations are a sign of an increased rate of triglyceride synthesis in the liver (Drackley et al., 2001). A recent study by McCarthy et al. (2015) has shown that serum BHB and fatty acids concentrations correlate poorly, which might be another explanation for our observation. In addition, as we observed an increase of approximately $45 \%$ in butyrate concentration in rumen fluid over the course of the trial [from $10.3 \mathrm{mmol} / \mathrm{L}$ in wk 1 , to $12.3 \mathrm{mmol} / \mathrm{L}$ in wk $5-7$, and to $14.9 \mathrm{mmol} / \mathrm{L}$ in wk 8-10; $P<0.01 ; \mathrm{n}=5$; PSEM $=0.65 ; \mathrm{M}$. Schären U. Meyer, S. Dänicke (Friedrich-Loeffler-Institute, Brunswick, Germany), M. Bulang (Martin-Luther-University Halle-Wittenberg, Halle, Germany), unpublished data], we suggest that the increased serum BHB concentrations might be attributed to an increased ketogenesis in the rumen epithelium rather than a subclinical ketosis (Baird, 1981; Baldwin and Jesse, 1996). However, we concluded that, to further elucidate the length and extent of the energy deficit in the PG, a prolongation of the experimental period would have been necessary.

As the cows were in the second half of their lactation, a continuous increase in body condition was expected in the CG. Instead, especially in wk 8 to 10 , a decrease in BCS combined with a stronger decrease in milk yield than expected was observed. During the trial, grass silage from 2 different silos was fed. Feed analysis after the trial revealed poor grass silage quality in both silos. The $\mathrm{CP}$ of the grass silage fed in wk 1 to 4 exhibited $\mathrm{CP}$ content of $151 \mathrm{~g} / \mathrm{kg}$ of DM, and the grass silage fed in wk 5 to 10 had CP content of $111 \mathrm{~g} / \mathrm{kg}$ of DM. Consequently, the CP content of the TMR was reduced and the RNB was negative $(-2.1$ and $-3.7 \mathrm{~g} / \mathrm{kg}$ of DM, respectively), especially in the second half of the trial. We assumed that the low CP content and a poor silage quality led to a decrease in body condition and milk yield in wk 8 to 10 in the CG. No significant increase in serum fatty acids concentrations indicated that no extensive lipomobilization occurred. Nevertheless, serum BHB concentrations were significantly elevated in that period, probably due to a subclinical ketosis due to a nutritional misbalance or increased silage butyrate concentrations (LeBlanc, 2010). A rather unexpected observation was the concurrent increase in serum urea concentration in wk 8 to 10 . We presumed that, due to an inadequate fermentation, AA degradation occurred, leading to an increased amount of $\mathrm{N}$ available in the form of ammonia instead of AA or peptides in the grass silage fed. As a consequence, efficiency of microbial synthesis was possibly hampered (Kim et al., 1999; Dijkstra et al., 2007) and excess ammonia and nonlimiting AA were metabolized and excreted, leading to increased serum urea concentrations. Another possible explanation is an increased tissue mobilization and a concurrent decrease in milk protein yield leading to an increase in hepatic deamination of mobilized AA from peripheral tissue (Wheelock et al., 2010).

Several studies have illustrated the decreasing effect of fresh grass and legumes on milk fat synthesis in dairy cows (White et al., 2001; Morales-Almaráz et al., 2010; Wiking et al., 2010). This effect was also observed in our study as soon as the PG was on a full grazing ration (wk 5). We hypothesized that the decreasing effect the unsaturated fatty acids in fresh grass on milk fat concentration of was partially compensated by the lipomobilizing effect of the energy deficit also present at that time. This was supported by an increase in wk 6 and a continuous decrease in milk fat concentration in wh 7 to 10 .

We did not observe any effect of an increased CP intake in the PG on milk protein concentrations, but, as expected, the excess ingested CP led to a significant increase in milk and serum urea concentrations. This concept of increased $\mathrm{N}$ excretion was further supported by an increased urine total $\mathrm{N}$-to-creatinine ratio in the PG in wk 4 and 10 and is a known phenomenon in dairy cows on a pasture- compared with a TMR-based diet (Kebreab et al., 2002; Keim and Anrique, 2011).

We observed an increased urine total N-to-creatinine concentration in wk 7 in PG as well as CG and no significant difference between groups was present due to high standard deviations at that point in time. The same pattern was observed for the PD-to-creatinine ratio. Even though earlier studies have confirmed the urine spot sampling, even throughout the day, as a valid method to estimate the total creatinine and 
PD output (Chizzotti et al., 2008), several factors in the present study could have affected the creatinine metabolism and thereby influenced the interpretability of the results. For example, urine creatinine concentrations halved in PG from wk 4 to 5, suggesting that the PG ingested more fluid due to a lower DM content of grass and a higher direct water intake. Another aspect that should be considered is that the muscle activity of the PG increased, possibly influencing the creatinine metabolism (Baxmann et al., 2008). In the CG, the urine creatinine concentration decreased substantially in wk 6 to 8 , indicating a higher water intake due to increased ambient temperature. This was confirmed by a significant correlation of urine creatinine concentrations with water intake. Various studies have discussed the THI threshold for heat stress in dairy cows. The general agreement is that it is localized somewhere between 60 and 70 depending on the climate zone, housing system, and dairy breed (Kellaway and Colditz, 1975; Zimbelman et al., 2009; Gorniak et al., 2014). In wk 7 , the THI was on average 6.6 points higher compared with wk 1, 4, and 10 indoors and outdoors, indicating possible heat stress for CG as well as PG in that period. Kellaway and Colditz (1975) and Wheelock et al. (2010) describe an increased muscle catabolism and decreased nitrogen retention in an experiment with Holstein-Friesian heifers and cows under heat stress. Therefore, we suggest that the high standard deviation in the urine total $\mathrm{N}$ - and $\mathrm{PD}$-to-creatinine ratios in wk 7 were caused by individual differences in the extent of catabolic processes triggered by heat stress. We further suspect that, due to difference in sampling days of blood and urine samples, no concurrent evolution of blood and urine urea variables was observed (blood samples were taken at the beginning of each week, whereas urine samples were collected throughout the week). We also observed a strong influence of the weather conditions on serum glucose concentrations. Our observation of a reciprocal relationship between THI and glucose agrees with multiple heat stress models and has been described previously in other studies (summarized in Wheelock et al., 2010). It is assumed that glucose is the favored fuel for heat-stressed animals, as adipose tissue mobilization probably causes an increase in metabolic heat production (Wheelock et al., 2010).

We observed a decline in urine $\mathrm{pH}$ in the $\mathrm{PG}$ from 8.03 in wk 1 to as low as 7.39 in wk 9. According to Roche et al. (2000), throughout the year the urine $\mathrm{pH}$ of dairy cows on a pasture-based diet was generally between 8.0 and 8.5 and was only lowered by a very low DCAD $(<15 \mathrm{mEq} / 100 \mathrm{~g})$ at certain times in the year. Given that we did not quantify the DCAD of the TMR nor the pasture, we can only speculate that the DCAD of pasture must have been lower than that of the TMR. However, as a urine $\mathrm{pH}$ in that range is considered physiological, we concluded that no adverse health effect of either ration could be deduced from urine $\mathrm{pH}$ measurements during the trial.

In agreement with our observations, several studies have described a lipomobilization and higher metabolic urea concentrations due to an energy deficit and an excess CP intake in pasture-based rations (Kolver and Muller, 1998; Bargo et al., 2002; Fontaneli et al., 2005). The aim of our study was to investigate if this increased metabolic load could imply a negative effect on liver health. No relevant increase was observed for $\gamma-\mathrm{GT}$, GLDH, AST, and bilirubin, demonstrating that the increased $\mathrm{N}$ conversion in the liver and consequently increased metabolic urea concentrations did not have any negative effects on liver cell vitality. In the PG a decrease in serum cholesterol and $\gamma$-GT concentrations were measured in wk 10. Dänicke et al. (2014) described a positive linear relationship between cholesterol and $\gamma$-GT in bovine serum under the influence of an increase in concentrate feed proportion; the increase in $\gamma$-GT might be a reflection of the increased cholesterol associated bile acid turnover. As the total daily lipid intake did not differ between groups in the present study, a different explanation would be that an increase in PUFA intake due to the pasture-based ration caused serum cholesterol to decrease and, consequently, the $\gamma$-GT activity to decrease. Ruminants receiving a pasture-based generally exhibit a higher cis-9,trans-11 CLA concentration in milk (White et al., 2001) and adipose tissue (Fincham et al., 2009) due to higher PUFA concentrations in pasture- compared with TMR-based diets. Reklewska et al. (2002) showed that when supplementing linseed ( $\alpha$-linolenic acid or PUFA source) in a TMR, the proportion of unsaturated fatty acids increases and the cholesterol level in the milk decreases. Unfortunately, studies illustrating the influence of an increased PUFA intake on blood metabolites, especially with a focus on pasture-based diets and cholesterol, are lacking.

To identify other possible influences of ration and housing system on the health status, we also measured immunological variables, such as serum protein and albumin concentrations, white blood cell, and milk SCC. Neither significant group effects nor biologically significant changes were observed at any time.

Red blood cell count revealed higher RBC, HCT, and HGB concentrations in the PG during the full grazing period compared with the CG. We assumed that these differences were possibly caused by increased activity of the PG due to grazing and walking, as well as differences in climate conditions indoors and outdoors (Lee et al., 1976; Hays et al., 1978; Fisher et al., 1980). But 
as the differences between groups were relatively small, we did not ascribe these observations a great biological significance. Changes in $\mathrm{MCV}, \mathrm{MCH}, \mathrm{MCHC}, \mathrm{RDW}$, and PDW did not reveal any conclusive differences between groups.

\section{CONCLUSIONS}

We hypothesized that the change from a confinement to a pasture-based system involved complex nutritional and metabolic adaptations with consequences on health and performance. This was confirmed by a lower DMI causing an energy deficit and lipomobilization during the transition from a TMR- to a pasture-based diet. These alterations in energy metabolism resulted in a lower milk production and loss in BW and BCS. After an initial sudden decrease DMI, milk production and $\mathrm{BW}$ increased continuously in the PG, indicating a metabolic as well as behavioral adaptation. Further research is needed to investigate whether an appropriate supplementation or a different grazing system would have attenuated the extent of the energy deficit observed. Due to a higher $\mathrm{CP}$ intake in the $\mathrm{PG}$, an increase in metabolic urea concentrations as well an increase in $\mathrm{N}$ excretion was observed. Metabolic health indicators, such as clinical chemistry and total blood cell counts, revealed no biological significant changes. We can therefore conclude that neither an increased exposure to higher $\mathrm{CP}$ feed intakes, the observed lipomobilization, nor any other attribute of the pasturebased system had any short-term negative effect on liver health.

\section{ACKNOWLEDGMENTS}

The authors thank the "Niedersächsisches Ministerium für Wissenschaft und Kultur" (Hannover, Germany) for financial support. Thanks are also due to the "Versuchsstation Haus Riswick" (Kleve, Germany) for scientific and material assistance associated with the pasture management. We thank Dirk Albers of the "Landwirtschaftskammer Niedersachsen" (Ovelgönne, Germany) for excellent consultancy and collaboration. We further thank Jan Dijkstra (Wageningen University, Wageningen, the Netherlands) for fruitful scientific discussions and exchange. Many thanks go to Berit Greune (Georg-August Universität, Göttingen, Germany) for assisting us in the pasture species assessment. Furthermore, the assistance of the coworkers at the Institute of Animal Nutrition and the experimental station of the Friedrich-Loeffler-Institute (FLI) in Brunswick, Germany, in caring for the experimental animals, assisting with experimental measurements, as well as performing the analyses is gratefully acknowledged.

\section{REFERENCES}

Abrahamse, P. A., S. Tamminga, and J. Dijkstra. 2009. Effect of daily movement of dairy cattle to fresh grass in morning or afternoon on intake, grazing behaviour, rumen fermentation and milk production. J. Agric. Sci. 147:721-730.

Alawneh, J. I., M. A. Stevenson, N. B. Williamson, N. Lopez-Villalobos, and T. Otley. 2012. The effect of liveweight change on reproductive performance in a seasonally calving, pasture fed dairy herd. Livest. Sci. 145:131-139.

Baird, G. D. 1981. Ruminant ketosis. Biochem. Soc. Trans. 9:348-349.

Baldwin, R. L. t., and B. W. Jesse. 1996. Propionate modulation of ruminal ketogenesis. J. Anim. Sci. 74:1694-1700.

Bargo, F., L. D. Muller, J. E. Delahoy, and T. W. Cassidy. 2002. Performance of high producing dairy cows with three different feeding systems combining pasture and total mixed rations. J. Dairy Sci. 85:2948-2963.

Bargo, F., L. D. Muller, E. S. Kolver, and J. E. Delahoy. 2003. Production and digestion of supplemented dairy cows on pasture. J. Dairy Sci. 86:1-42.

Baxmann, A. C., M. S. Ahmed, N. C. Marques, V. B. Menon, A. B. Pereira, G. M. Kirsztajn, and I. P. Heilberg. 2008. Influence of muscle mass and physical activity on serum and urinary creatinine and serum cystatin C. Clin. J. Am. Soc. Nephrol. 3:348-354.

Burow, E., P. T. Thomsen, J. T. Sorensen, and T. Rousing. 2011. The effect of grazing on cow mortality in Danish dairy herds. Prev. Vet. Med. 100:237-241.

Chizzotti, M. L., S. de Campos Valadares Filho, R. F. D. Valadares, F. H. M. Chizzotti, and L. O. Tedeschi. 2008. Determination of creatinine excretion and evaluation of spot urine sampling in Holstein cattle. Livest. Sci. 113:218-225.

Dänicke, S., U. Meyer, J. Winkler, K. Schulz, S. Ulrich, J. Frahm, S. Kersten, J. Rehage, G. Breves, and S. Häußler. 2014. Description of a bovine model for studying digestive and metabolic effects of a positive energy balance not biased by lactation or gravidity. Arch. Anim. Nutr. 68:460-477.

Decruyenaere, V., A. Buldgen, and D. Stilmant. 2009. Factors affecting intake by grazing ruminants and related quantification methods: A review. Base 13:559-573.

Dijkstra, J., E. Kebreab, J. A. Mills, W. F. Pellikaan, S. Lopez, A. Bannink, and J. France. 2007. Predicting the profile of nutrients available for absorption: From nutrient requirement to animal response and environmental impact. Animal 1:99-111.

Dillon, P., J. Roche, L. Shalloo, and B. Horan. 2005. Optimising financial return from grazing in temperate pastures. Pages 131-147 of Utilisation of grazed grass in temporal animal systems. Proceedings of a Satellite Workshop of the XX International Grassland Congress, Cork, Ireland, July 2005. CABI, Wallingford, UK.

DLG. 1997. Deutsche Landwirtschafts-Gesellschaft, DLG-Futterwerttabellen, Wiederkäuer. Vol. 7. Universität Hohenheim, Frankfurt am Main, Germany.

Dove, H., and R. W. Mayes. 1996. Plant wax components: A new approach to estimating intake and diet composition in herbivores. J. Nutr. 126:13-26.

Dove, H., and R. W. Mayes. 2006. Protocol for the analysis of n-alkanes and other plant-wax compounds and for their use as markers for quantifying the nutrient supply of large mammalian herbivores. Nat. Protoc. 1:1680-1697.

Drackley, J. K., T. R. Overton, and G. N. Douglas. 2001. Adaptations of glucose and long-chain fatty acid metabolism in liver of dairy cows during the periparturient period. J. Dairy Sci. 84:E100-E112.

Edmonson, A. J., I. J. Lean, L. D. Weaver, T. Farver, and G. Webster. 1989. A Body condition scoring chart for Holstein dairy cows. J. Dairy Sci. 72:68-78.

Elwert, C., H. Kluth, and M. Rodehutscord. 2004. Effect of variable intake of alfalfa and wheat on faecal alkane recoveries and estimates of roughage intake in sheep. J. Agric. Sci. 142:213-223.

Fincham, J. R., J. Fontenot, W. Swecker, J. Herbein, J. Neel, G. Scaglia, W. Clapham, and D. Notter. 2009. Fatty acid metabolism and deposition in subcutaneous adipose tissue of pasture-and feedlotfinished cattle. J. Anim. Sci. 87:3259-3277. 
Fisher, D. D., L. L. Wilson, and R. W. Scholz. 1980. Environmental and genetic effects on hematologic characteristics of beef cows. Am. J. Vet. Res. 41:1533-1536.

Fontaneli, R. S., L. E. Sollenberger, R. C. Littell, and C. R. Staples, 2005. Performance of lactating dairy cows managed on pasturebased or in freestall barn-feeding systems. J. Dairy Sci. 88:12641276 .

GfE. 2001. Empfehlungen zur Energie- und Nährstoffversorgung der Milchkühe und Aufzuchtrinder. DLG-Verlags GmbH, Frankfurt am Main, Germany.

GfE. 2008. Neue Gleichungen zur Schätzung der umsetzbaren Energie für Wiederkäuer von Gras- und Maisprodukten (New equations for predicting metabolisable energy of grass and maize products for ruminants). Proc. Soc. Nutr. Physiol. No. 17. GfE (Society for Nutrition Physiology), Frankfurt am Main, Germany.

Goldberg, J. J., E. Wildman, J. Pankey, J. Kunkel, D. Howard, and B. Murphy. 1992. The influence of intensively managed rotational grazing, traditional continuous grazing, and confinement housing on bulk tank milk quality and udder health. J. Dairy Sci. 75:96-104.

Gorniak, T., U. Meyer, K.-H. Südekum, and S. Dänicke. 2014. Impact of mild heat stress on dry matter intake, milk yield and milk composition in mid-lactation Holstein dairy cows in a temperate climate. Arch. Anim. Nutr. 68:358-369.

Hahn, G. L. 1999. Dynamic responses of cattle to thermal heat loads. J. Anim. Sci. 77:10-20

Haskell, M. J., L. J. Rennie, V. A. Bowell, M. J. Bell, and A. B. Lawrence. 2006. Housing system, milk production, and zero-grazing effects on lameness and leg injury in dairy cows. J. Dairy Sci. 89:4259-4266.

Hays, F. L., W. Bianca, and F. Naf. 1978. Effects of exercise on young and adult cattle at low and high altitude. Int. J. Biometeorol. $22: 147-158$

Kebreab, E., J. France, J. A. Mills, R. Allison, and J. Dijkstra. 2002. A dynamic model of $\mathrm{N}$ metabolism in the lactating dairy cow and an assessment of impact of $\mathrm{N}$ excretion on the environment. J. Anim. Sci. 80:248-259.

Keim, J. P., and R. Anrique. 2011. Nutritional strategies to improve nitrogen use efficiency by grazing dairy cows. Chil. J. Agric. Res. 71:623-633.

Kellaway, R., and P. Colditz. 1975. The effect of heat stress on growth and nitrogen metabolism in Friesian and F1 Brahman $\times$ Friesian heifers. Crop Pasture Sci. 26:615-622.

Kim, C. H., J. J. Choung, and D. G. Chamberlain. 1999. Determination of the first-limiting amino acid for milk production in dairy cows consuming a diet of grass silage and a cereal-based supplement containing feather meal. J. Sci. Food Agric. 79:1703-1708.

Kolver, E. S. 2003. Nutritional limitations to increased production on pasture-based systems. Proc. Nutr. Soc. 62:291-300.

Kolver, E. S., and L. D. Muller. 1998. Performance and nutrient intake of high producing Holstein cows consuming pasture or a total mixed ration. J. Dairy Sci. 81:1403-1411.

LeBlanc, S. 2010. Monitoring metabolic health of dairy cattle in the transition period. J. Reprod. Dev. 56:S29-S35.

Lee, J. A., J. D. Roussel, and J. F. Beatty. 1976. Effect of temperatureseason on bovine adrenal-cortical function, blood-cell profile, and milk-production. J. Dairy Sci. 59:104-108.

Legrand, A. L., M. A. von Keyserlingk, and D. M. Weary. 2009. Preference and usage of pasture versus free-stall housing by lactating dairy cattle. J. Dairy Sci. 92:3651-3658.

Mayne, C. S., I. A. Wright, and G. E. J. Fisher. 2000. Chapter 10 Grassland Management under Grazing and Animal Response. Pages 229-246 in Grass: Its Production and Utilization. A. Hopkins, ed. Blackwell Science Ltd. Hoboken, NJ.

McCarthy, M. M., S. Mann, D. V. Nydam, T. R. Overton, and J. A. A. McArt. 2015. Transition period concentrations of nonesterified fatty acids and $\beta$-hydroxybutyrate in dairy cows are not well correlated. Meeting Abstracts ADSA-ASAS Joint Annual Meeting. J. Dairy Sci. 98(Suppl. 2):705.

Moller, S., C. Mathew, and G. Wilson. 1993. Pasture protein and soluble carbohydrate levels in spring dairy pasture and associations with cow performance. Pages 83-83 in Proceedings of the New Zealand Society of Animal Production. New Zealand Society of Animal Production, Cambridge, New Zealand.

Morales-Almaráz, E., A. Soldado, A. Gonzalez, A. Martinez-Fernandez, I. Dominguez-Vara, B. de la Roza-Delgado, and F. Vicente. 2010. Improving the fatty acid profile of dairy cow milk by combining grazing with feeding of total mixed ration. J. Dairy Res. $77: 225-230$.

O'Neill, B. F., M. H. Deighton, B. M. O'Loughlin, F. J. Mulligan, T. M. Boland, M. O'Donovan, and E. Lewis. 2011. Effects of a perennial ryegrass diet or total mixed ration diet offered to springcalving Holstein-Friesian dairy cows on methane emissions, dry matter intake, and milk production. J. Dairy Sci. 94:1941-1951.

Olmos, G., L. Boyle, A. Hanlon, J. Patton, J. J. Murphy, and J. F. Mee. 2009a. Hoof disorders, locomotion ability and lying times of cubicle-housed compared to pasture-based dairy cows. Livest. Sci. $125: 199-207$

Olmos, G., J. F. Mee, A. Hanlon, J. Patton, J. J. Murphy, and L. Boyle. 2009b. Peripartum health and welfare of Holstein-Friesian cows in a confinement-TMR system compared to a pasture-based system. Anim. Welf. 18:467-476.

Osuji, P. O. 1974. Physiology of eating and energy expenditure of ruminant at pasture. J. Range Manage. 27:437-443.

Pacheco, D., and G. C. Waghorn. 2008. Dietary nitrogen-Definitions, digestion, excretion and consequences of excess for grazing ruminants. Pages 107-116 in Proc. New Zealand Grassland Association. New Zealand Grassland Association, Mosgiel Dunedin, New Zealand.

Parker, W., and N. Edwards. 1996. Within-year variation in pasture quality has implications for dairy cow nutrition. Pages 173-177 in Proceedings of the New Zealand Grassland Association, vol 57. New Zealand Grassland Association, Mosgiel Dunedin, New Zealand.

Pfeffer, E., and A. Hristov. 2005. Nitrogen and Phosphorus Nutrition of Cattle. CAB International, Wallingford, UK

Rajala-Schultz, P. J., W. J. A. Saville, G. S. Frazer, and T. E. Wittum. 2001. Association between milk urea nitrogen and fertility in Ohio dairy cows. J. Dairy Sci. 84:482-489.

Reeves, M., W. J. Fulkerson, R. C. Kellaway, and H. Dove. 1996. A comparison of three techniques to determine the herbage intake of dairy cows grazing kikuyu (Pennisetum clandestinum) pasture. Aust. J. Exp. Agric. 36:23-30.

Reklewska, B., A. Oprzadek, Z. Reklewski, L. Panicke, B. Kuczynska, and J. Oprzadek. 2002. Alternative for modifying the fatty acid composition and decreasing the cholesterol level in the milk of cows. Livest. Prod. Sci. 76:235-243.

Ribeiro, E. S., F. S. Lima, L. F. Greco, R. S. Bisinotto, A. P. Monteiro, M. Favoreto, H. Ayres, R. S. Marsola, N. Martinez, W. W. Thatcher, and J. E. Santos. 2013. Prevalence of periparturient diseases and effects on fertility of seasonally calving grazing dairy cows supplemented with concentrates. J. Dairy Sci. 96:5682-5697.

Roca-Fernandez, A. I., C. P. Ferris, and A. Gonzalez-Rodriguez. 2013 Short communication. Behavioural activities of two dairy cow genotypes (Holstein-Friesian vs. Jersey x Holstein-Friesian) in two milk production systems (grazing vs. confinement). Span. J. Agric. Res. 11:120-126.

Roche, J. R., D. Dalley, P. Moate, C. Grainger, M. Hannah, F. O'Mara, and M. Rath. 2000. Variations in the dietary cation-anion difference and the acid-base balance of dairy cows on a pasture-based diet in south-eastern Australia. Grass Forage Sci. 55:26-36.

Smit, H., A. Elgersma, A. Lúscher, B. Jeangros, W. Kessler, O. Huguenin, M. Lobsiger, N. Millar, and D. Suter. 2004. Diurnal fluctuations in vertical distribution of chemical composition in a perennial ryegrass (Lolium perenne L.) sward during the season. Pages 951-953 in Proc. Land Use Systems in Grassland Dominated Regions. Proceedings of the 20th General Meeting of the European Grassland Federation, Luzern, Switzerland, 21-24 June 2004. vdf Hochschulverlag AG an der ETH, Zurich, Switzerland.

Smit, H. J., H. Z. Taweel, B. M. Tas, S. Tamminga, and A. Elgersma. 2005. Comparison of techniques for estimating herbage intake of grazing dairy cows. J. Dairy Sci. 88:1827-1836. 
Smith, J., S. Beaumont, L. Hagemann, R. McDonald, A. Peterson, Z. Xu, and D. Duganzich. 2001. Relationship between bulk milk urea nitrogen and reproductive performance of New Zealand dairy herds. Pages 192-194 in Proceedings of the New Zeland Society of Animal Production. New Zealand Society of Animal Production, Cambridge, New Zealand.

Taweel, H. Z., B. M. Tas, H. J. Smit, A. Elgersma, J. Dijkstra, and S. Tamminga. 2006. Grazing behaviour, intake, rumen function and milk production of dairy cows offered Lolium perenne containing different levels of water-soluble carbohydrates. Livest. Sci. 102:33-41.

VDLUFA. 2006. Verband Deutscher Landwirtschaftlicher Untersuchungs-und Forschungsanstalten. Handbuch der Landwirtschaftlichen Versuchs-und Untersuchungsmethodik (VDLUFA-Methodenbuch), Bd. III Die chemische Untersuchung von Futtermitteln. VDLUFA-Verlag, Darmstadt, Germany.

Washburn, S. P., S. L. White, J. T. Green, and G. A. Benson. 2002. Reproduction, mastitis, and body condition of seasonally calved Holstein and Jersey cows in confinement or pasture systems. J. Dairy Sci. 85:105-111.

Wheelock, J. B., R. P. Rhoads, M. J. VanBaale, S. R. Sanders, and L. H. Baumgard. 2010. Effects of heat stress on energetic metabolism in lactating Holstein cows. J. Dairy Sci. 93:644-655.
White, S. L., J. A. Bertrand, M. R. Wade, S. P. Washburn, J. T Green, and T. C. Jenkins. 2001. Comparison of fatty acid content of milk from jersey and Holstein cows consuming pasture or a total mixed ration. J. Dairy Sci. 84:2295-2301.

Wiking, L., P. K. Theil, J. H. Nielsen, and M. T. Sørensen. 2010. Effect of grazing fresh legumes or feeding silage on fatty acids and enzymes involved in the synthesis of milk fat in dairy cows. J. Dairy Res. 77:337-342.

Winkler, J., S. Kersten, H. Valenta, L. Hüther, U. Meyer, U. Engelhardt, and S. Dänicke. 2014. Simultaneous determination of zearalenone, deoxynivalenol and their metabolites in bovine urine as biomarkers of exposure. World Mycotoxin J. 8:63-74.

Zimbelman, R., R. Rhoads, M. Rhoads, G. Duff, L. Baumgard, and R. Collier. 2009. A re-evaluation of the impact of temperature humidity index (THI) and black globe humidity index (BGHI) on milk production in high producing dairy cows. Pages 26-27 in Proc. Proceedings of the Southwest Nutrition and Management Conference, Tempe, AZ. University of Arizona, Tucson. 